\title{
Fat Intake and CNS Functioning: Ageing and Disease
}

\author{
Michael A. Crawford ${ }^{a}$ Richard P. Bazinet ${ }^{b}$ Andrew J. Sinclair ${ }^{c}$ \\ a Institute of Brain Chemistry and Human Nutrition, London Metropolitan University, London, UK; \\ ${ }^{b}$ Department of Nutritional Sciences, Faculty of Medicine, University of Toronto, Toronto, Ont., Canada; \\ 'School of Exercise and Nutrition Sciences, Deakin University, Burwood, Vic., Australia
}

\section{Brain Composition}

The brain contains little parent essential fatty acid (EFA) and typically has arachidonic (AA), docosatetraenoic and docosahexaenoic acids (DHA) as the principal polyenoic fatty acids. Although the size of the brain differs between mammalian species, the profile of AA and DHA does not vary [Crawford et al., 1976a, 1993], suggesting a high degree of evolutionary conservation of the neural lipid profile (fig. 1). DHA is rapidly and selectively incorporated in the stereospecifically numbered (sn)-2 position of neural phospholipid membranes, and is concentrated in the photoreceptor [Benolken et al., 1975; Fliesler and Anderson, 1983] and selectively at synaptic signalling sites [Suzuki et al., 1997]. It is the most unsaturated of the cell membrane fatty acids in the brain [Jump, 2002]. DHA is synthesised from $\alpha$-linolenic acid (ALA). However, ALA is $\beta$-oxidised at a rapid rate [Leyton et al., 1987] and its desaturation - and hence conversion to DHA - is rate limited, especially in the brain [Sprecher 1993, 1999; Rapoport et al., 2007].

Dr. Elizabeth Manickam (Deakin University, Australia), Dr. Cecile Delcourt (INSERM, Bordeaux, France), Dr. V. Flood and Prof. P. Mitchell (University of Sydney, Australia), Ms. Catherine Lehane and Prof. Kebreab Ghebremeskel (IBCHN, London Metropolitan University, UK) contributed to the writing of this paper.

\section{KARGER}

Fax +4161306 1234 E-Mail karger@karger.ch www.karger.com
(C) 2009 S. Karger AG, Basel and FAO

0250-6807/09/0553-0202\$26.00/0

Accessible online at:

www.karger.com/anm
In 1972, Crawford and Sinclair published evidence that AA and DHA were independent determinants of brain growth and evolution [Crawford and Sinclair 1972; Broadhurst et al., 2002; Enard et al., 2002; Pennisi 2002]. Deficiency studies in rodents [Sinclair and Crawford 1972; Benolken et al., 1973; Galli and Socini, 1983; Weisinger et al., 1999; Catalan et al., 2002], chickens [Budowski et al., 1987], primates [Fiennes et al., 1973; Neuringer et al., 1986], and visual and cognitive trials in human infants [Carlson and Werkman, 1996; Martinez and Vazquez, 1998; Birch et al., 2000] have indicated that both AA and DHA are essential for brain development and function. Moreover, the competition that exists between $\mathrm{n}-6 / \mathrm{n}-3$ fatty acids applies to their balance being critical for brain development and structural integrity [Budowski and Crawford, 1985]. DHA is essential in vision, brain neurones and cell signalling.

\section{What Is the Role of DHA in the Brain?}

Dietary-induced reductions in brain DHA in animals, resulting from feeding on a diet deficient in $n-3$, are associated with many changes in brain function including alterations in learning and memory [Suzuki et al., 2001], auditory [Haubner et al., 2002] and olfactory [Greiner et al., 2001] responses to stimuli, reductions in the size of neurons, changes in nerve growth factor levels [Sinclair

Tel. +44 207133 2926, E-Mail michael@macrawf.demon.co.uk 
Fig. 1. PUFA profiles in human arterial endothelium and brain.
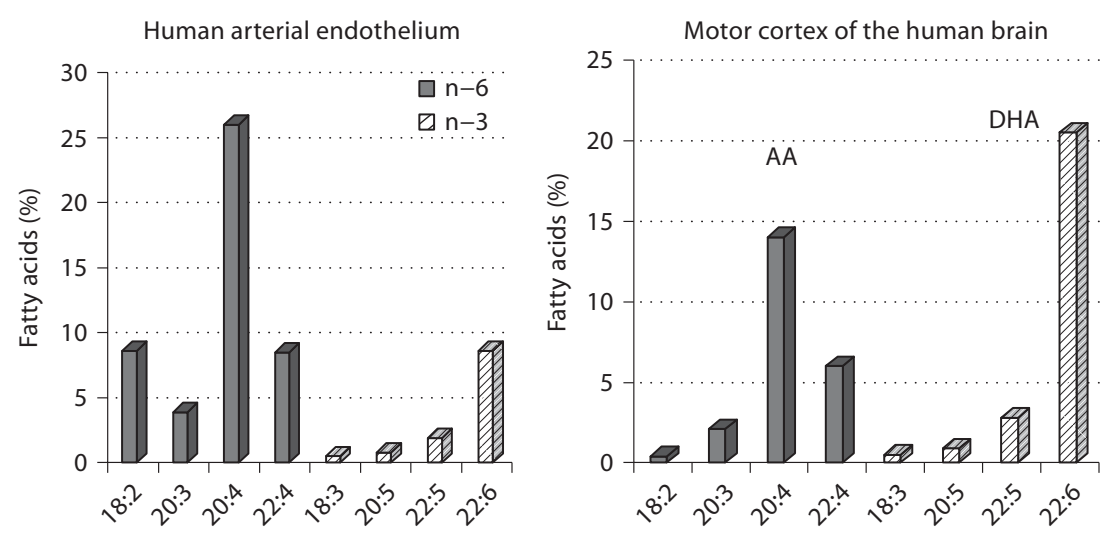

et al., 2007], delayed cell migration in the developing brain [Yavin et al., 2009] and an increase in depressive and aggressive behaviour [DeMar et al., 2006].

Various mechanisms have been suggested to account for these physiological changes, including alterations in membrane function (physical properties, receptor function, neurotransmission, membrane-related enzyme activity, glucose transport, signal transduction) [for review, see Sinclair et al., 2007], changes in the expression of many genes in the brain [for review, see Kitajka et al., 2004], electron transfer [Crawford et al., 2008], changes in eicosanoid and docosanoid production (known to be involved in learning and memory), neuroinflammation and perhaps depression [Horrocks and Yeo, 1999]. Antiarrhythmic properties are thought due to modulation of voltage-gated $\mathrm{Na}^{+}$and L-type $\mathrm{Ca}^{2+}$ channels [Xiao et al., 2005]. The same influence on electrophysiology was also shown to operate on neuronal excitability [Vreugdenhil et al., 1996]. Whilst the electrophysiological influence is seen with both EPA and DHA in cardiac myocytes, there is only DHA in the brain membrane lipids (fig. 1). Indeed, most membrane lipids contain very little EPA. Whilst DHA is clearly concentrated in the signalling systems of the brain (fig. 1), EPA is more likely to be involved in vascular, blood flow and eicosanoid activity where it and its own eicosanoids can compete with and down-regulate the AA metabolites to maintain homeostasis and participate in the response to injury.

Under the control of specific stimuli, polyunsaturated fatty acids (PUFA) are released from the glycerophospholipids by the action of various phospholipases and are metabolised by cyclooxygenase (COX) and lipoxygenase (LOX) enzymes into a variety of oxygenated PUFA de- rivatives known as eicosanoids (prostaglandins, thromboxanes, lipoxins, leukotrienes, hydroxyeicosatetraenoic and epoxyeicosatetraenoic acids) and docosatrienes (neuroprotectins and resolvins) which are locally acting hormone-like compounds. COX and LOX are involved in the production of pro-inflammatory metabolites of $\mathrm{AA}$, including prostaglandins and thromboxanes (COXderived) and leukotrienes (LOX-derived), respectively. LOX also generates anti-inflammatory DHA-derived metabolites (neuroprotectins and resolvins) and lipoxins derived from AA via the 5-LOX pathway. Non-steroidal anti-inflammatory drugs, such as aspirin and ibuprofen, have been used to prevent inflammation and have recently been implicated as potential therapeutics for neurodegenerative disease [Leone et al., 2007].

\section{EFA and the Brain}

A comprehensive review of the field has been written by Lauritzen et al. [2001]. There are 2 families of EFA that have to be obtained in the food. The $\mathrm{n}-6$, starting with linoleic acid, which occurs in seeds and is desaturated and elongated in animals to introduce more degrees of polyunsaturation and longer chain lengths (from 18 carbons to 20 and 22; fig. 1).

The second is the $\mathrm{n}-3$ family, starting with ALA, which occurs in photosynthetic systems (e.g. green vegetation). It is similarly desaturated and chain elongated to eicosapentaenoic acid (EPA, 20:5n-3) and then to DHA (22:6n-3). The double bonds between the carbons that make up the polyunsaturation are separated by single methyl carbon units, and the sequence in the 2 families starts at different 


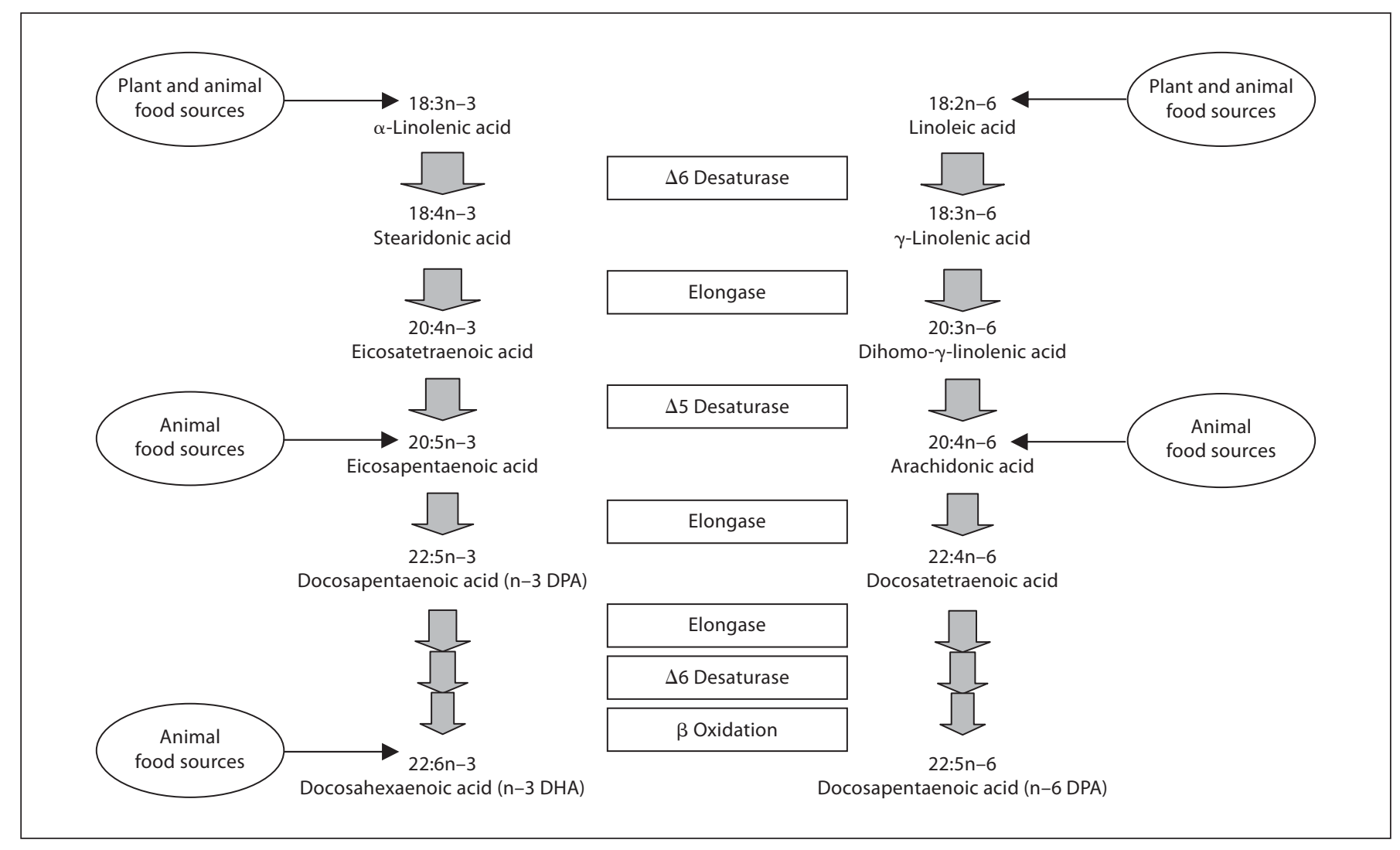

Fig. 2. Desaturation and elongation of $\alpha$-linolenic and linoleic acid.

positions numbered from the methyl end (n-6 and n-3). These end double bonds (from the $\mathrm{n}-9$ position) cannot be inserted by animals, although they can add more at the carboxyl end of the molecules, and so make up the more highly unsaturated fatty acids providing animal cells with a higher degree of membrane and physiological complexity compared with plants. Note however, the synthesis of the multiple double bonds requires both an oxidative process to remove the hydrogens and a final $\beta$-oxidation in the step from 24:6 to 22:6 (fig. 2).

The $\mathrm{n}-6$ family is essential for mammalian reproduction. AA is important in the blood vessels, being particularly rich in the inner cell membrane lipid (ethanolamine phosphoglyceride; fig. 1). Following phospholipase $A_{2}$ activity, $A A$ is released and converted into eicosanoids that maintain adequate blood flow (prostacyclin) or to stop blood flow in the case of injury (thromboxanes).

The synthesis of AA and especially DHA is rate limited and very slow, so there are advantages nutritionally to have them already made in the diet, especially during pre- and early postnatal development. Rapoport et al. [2007] have shown that in rats, the liver upregulates the conversion of ALA to DHA (but not in the brain) on diets low in ALA and devoid of DHA, slowing the loss of DHA from the brain during recycling and due to any peroxidation. AA and DHA are selectively incorporated into the brain at an early stage [Sinclair and Crawford, 1972] in striking preference to their synthesis from precursors [Sinclair, 1975].

It is important to note that both AA and DHA are essential in different ways. There is more long-chain $n-6$ than $\mathrm{n}-3$ in the brain of over 30 mammalian species so far studied [Crawford and Sinclair, 1972; Crawford et al., 1976a]. Brain AA is the precursor of a number of different endocannabinoids and eicosanoids which play important roles in the normal homeostasis of brain function [Tassoni et al., 2008]. $\mathrm{PGD}_{2}$ is crucial for the induction of sleep, and $\mathrm{PGE}_{2}$ and $\mathrm{PGD}_{2}$ are important signalling molecules in short-term and long-term memory formation, in a cascade involving brain-derived neurotrophic factor (BDNF) [Gomez-Pinilla, 2008; Stahl et al., 2008]. AA is 
also released from the sn-2 position of neural phospholipids by phospholipase $\mathrm{A}_{2}$ coupling to dopaminergic, serotonergic, glutamatergic and cholinergic neuroreceptor activation. In addition, the inositol phosphoglycerides are rich in AA. In the activation events, the resultant stearoyl-arachidonoyl-diacylglycerol is specifically involved in the activation of protein kinase $\mathrm{C}$ [Hindenes et al., 2000]. A recent review by Gomez-Pinilla [2008] considers the effects of nutrients on brain function at a physiological and molecular level.

Both AA and DHA can be synthesised from their plant precursors, but during early development in humans, the placenta specifically selects preformed AA and DHA biomagnifying their proportions for foetal plasma, AA much more so than DHA. The proportion of AA in maternal plasma and red cell choline phosphoglycerides is typically about $6-9 \%$ of the fatty acids, whereas in the foetus it can be more than double this value. At the same time, the linoleic acid proportion is halved. There is little or no further amplification of AA beyond the foetal liver. However, the proportion of DHA is amplified again as it arrives in the foetal liver from the plasma and again in the brain [Crawford et al., 1976b]. That the biomagnification process by the placenta is primarily one of specific selection of long-chain PUFA is supported by the lack of enzymes relevant to the desaturation and chain elongation process in the placenta [Crawford, 2000]. In any event, there is very little precursor for DHA (e.g. ALA and EPA) transferred by the placenta, which makes the often discussed issue as to whether the foetus can synthesise DHA somewhat academic.

It is noteworthy that the placenta is basically a rapidly growing vascular system which is rich in AA. In studies of human placentas at the earliest time from selected abortions, the proportion of AA was found to be even higher than at term [Bitsanis et al., 2006]. The negative press given to AA (that it is pro-thrombotic, pro-inflammatory etc.) may be misplaced. It disregards its positive structural and functional role in the vasculature and the brain.

This special treatment for AA by the placenta may well be to serve the development of the immune and vascular systems: both are AA rich. The vascular system in the placenta, embryo and early foetus develops ahead of the foetal brain growth spurt which occurs in the last trimester. The intense vascular development is a logical preparation for the phenomenally high energy demand imposed by the foetal brain growth.

AA is present in human milk, meat, eggs and some tropical fish. DHA is richest in the marine food chain, which is where the brain evolved 500-600 million years ago using DHA for signalling. Despite this long period of genomic change and species modifications, DHA has been found to be used in dinoflagelates, teleosts, amphibians, reptiles, birds, mammals and humans. Despite the precursor of DHA with only 1 double bond less (docosapentaenoic acid, 22:5n-3) being readily available, more easily synthesised and less susceptible to peroxidation, it never replaced DHA in photoreception or neural signalling. This is compelling evidence that DHA is essential, specifically to photoreception and the brain.

This high degree of specificity for DHA in neural signalling systems is unlikely to be due to liquidity because the difference between 5 and 6 double bonds is marginal [Bloom et al., 1999]. However, molecular dynamic studies suggest that DHA may have unique electrical properties operating as a type of semi-conducting device which would not be feasible if 1 double bond were to be removed. The quantum properties of tunnelling electrons would provide an absolute energy level at which the signal would operate offering a theoretical explanation for the necessary precision of response in phototransduction and synaptic signalling [Crawford et al., 2008].

\section{The n-3/n-6 Ratio for Neurodevelopment and Maintenance}

Because the enzymes involved in the metabolism of the EFA are shared, there is competition between them (fig. 2); the balance between EFA and their PUFA metabolites in the diet is vital. In humans, the brain is the most outstanding biological development: it follows that the priority is brain growth and development, and in that organ the balance between $n-6$ and n-3 PUFA metabolites is close to $1: 1$.

We argue that this ratio (between 2:1 to 1:1) should be the target for recommendations and a balanced diet for human nutrition. However, in modern foods, this ratio has slipped to between 10:1 and 20:1. This high n-6 proportion is largely made up today by linoleic acid, is far from optimal and thought to be highly disadvantageous [Hibbeln et al., 2006a, b].

Some consider that the proportion or ratio between the 2 families is not relevant. This consideration is largely because a high level of linoleic acid (18:2n-6) in the diet is thought to be advantageous to reduce blood cholesterol and help prevent heart disease. The link between linoleic acid and blood cholesterol is considered to be independent of $\mathrm{n}-3$ fatty acids. This approach is derived from US data on blood cholesterol and does not take into ac- 
count the converse. In some other countries, notably Japan, where there are low levels of dietary and tissue linoleic acid but high levels of long-chain n-3 fatty acids, heart disease is less prevalent than in Western countries. In addition, in the USA, the high level of linoleic acid would simply overwhelm variation in the very low level of ALA. In Japan, the wide variation in blood cholesterol does not fit with death from heart disease as it does in the USA [Lands, 2008].

It is a fundamental principle of biochemistry that similar molecules compete for enzyme active centres and in other ways. This principle is well known to operate between the different members of the $n-3$ and $n-6$ families of EFA which regulate each other [Mohrhauer and Holman, 1963; Budowski and Crawford, 1985]. The proportions of $n-3$ to $n-6$ in the diet is a determinant of biochemical efficiency which is important in providing the optimal conditions for neurodevelopment and for maintenance of the brain's EFA resources during the recycling processes and repair. Hence, approaching the ideal ratio of 2:1 or 1:1 could be of relevance to both neurodevelopment and the prevention of early neurodegeneration [Crawford et al., 2003; Lukiw and Bazan, 2008].

\section{Reason for Concern: Brain Disorders and Mental III Health}

The costs associated with brain disorders and mental ill health have been rising sharply, and have now overtaken those of any other health burden. There is good evidence to implicate poor conditions at the start of life as a fundamental cause of disturbed development leading to high susceptibility to mental ill health. Moreover, mental ill health contributes to overall health inequalities that are very common and is significantly associated with other lifestyle factors that are health risks, such as obesity, smoking, alcohol, substance abuse, and also with physical illness. In the UK, the costs associated with mental health problems are estimated to be GBP 77 billion a year; however, mental health does not have the high profile these costs would suggest. This was noted by Dr. Jo Nurse, the UK Department of Health's National Lead for Public Mental Health and Well-Being, when she spoke at the Westminster Health Forum Keynote Seminar on July 17, 2008. She said:

The impact of obesity - being about GBP 4 billion - is what is in most people's minds. It should be noted that GBP 77 billion is close to the whole of the funding for the UK NHS [the country's publicly run National Health Service], so it is a huge cost, and it is about $4 \%$ of GDP, as calculated by Richard Layard. In the UK, the cost of brain disorders is now greater than that of heart disease or cancer, the 2 most common causes of mortality from ill health.

The steepest rise in mental ill health has been among young children [Hibbeln, pers. commun.]. In 1972, it was predicted that brain disorders would rise following the rise in death from heart disease [Crawford and Crawford, 1972]. The prediction was based on: (i) the evidencebased causal relationship considered to exist between hard, saturated dietary fats and cardiovascular disease; (ii) the dependence of brain development on prior vascular development, first in the placenta and then the foetus, and (iii) the similarity of nutritional requirements for specialised dietary fats for brain and vascular development and function. That prediction has been fulfilled. Brain disorders have now overtaken all other burdens of ill health in the UK and also in the 25 member states of the EU (costing EUR 386 billion at 2004 prices) [AndlinSobocki et al., 2005].

The reason for linking heart disease and brain disorders is that during early development, the brain relies heavily on a pre-existing and efficient placental vascular and foetal cardiovascular system. The foetal brain uses $70 \%$ of the energy transferred to the foetus from the placenta. The placenta itself is a rapidly growing vascular system which needs to be in place ahead of the foetal brain growth spurt of the last trimester. Hence, healthy brain development is very much dependent on a good cardiovascular circulation. Put simply, if the cardiovascular system is under attack in an adult from distorted nutrition, the brain in the next generation(s) is likely to follow.

This paper raises several questions about the role of DHA in the brain and its extreme conservation in signalling systems with its possible relevance to human evolution. Importantly, it raises a question on how to meet the challenge of human mental health in face of the problems in aquatic food resources. The Global Forum for Health predicts that by 2020 mental ill health will be in the top 3 health burdens worldwide, alongside heart disease and perinatal conditions. All 3 of these conditions/diseases have common denominators in adverse nutrition and are related and relevant to both neurogenesis and neurodegeneration.

This paper further considers the evidence for the normal daily requirements of the adult brain for AA and DHA, the role of dietary fats (mainly long-chain PUFA) in various neuropsychological conditions and in age-related macular degeneration, and where the many gaps are in the literature. 


\section{Arachidonic Acid}

It is often concluded that AA can be synthesised from linoleic acid without difficulty. The early isotope studies by James Mead and Andrew Sinclair demonstrated that this was not the case [Sinclair, 1975]. As referred to earlier, the human placenta is extremely rich in AA and it might be considered as a super pump transferring it to the foetus. Indeed, the human placenta is much more active in transferring AA to the foetus than it is for DHA. There is also evidence from myographic studies of vascular function that it acts as an endothelial-derived relaxant, a property not witnessed with DHA or fully with EPA [Crawford et al., 2003].

However, many authors focus on the inflammatory and thrombotic mediators derived from $\mathrm{AA}$ almost to the point of labelling it as a toxic substance which cannot be the case. For $99.9 \%$ of our time, vasodilatory and anti-adhesive eicosanoids are being synthesised from the rich source of AA in the endothelium. Indeed, the US Food and Drug Administration commented on the pharmaceutical suppression of COX2 to down-regulate the inflammatory properties, affecting prostacyclin synthesis and hence contributing to the excess of deaths in the patients being so treated [e.g. Ray et al., 2002; James and Cleland, 2004].

There are some locations in the brain with much more AA and its elongation product than DHA. Serhan et al. [2008] make the point in a recent paper:

The popular view that all lipid mediators are pro-inflammatory arises largely from the finding that non-steroidal anti-inflammatory drugs block the biosynthesis of prostaglandins. The resolution of inflammation was widely held as a passive event until recently, with the characterisation of novel biochemical pathways and lipid-derived mediators that are actively turned on in resolution and that possess potent anti-inflammatory and proresolving actions. A lipid-mediator informatics approach was employed to systematically identify new families of endogenous local-acting mediators from n-3 PUFA (EPA and DHA) in resolving exudates, which also contain lipoxins and aspirin-triggered lipoxins generated from AA.

Figure 3 illustrates the reason why there is a question regarding the capability of the preterm infant to efficiently synthesise AA from linoleic acid. Whilst there are many issues affecting the metabolism of the preterm infant and stable isotope data indicate conversion, the reality of the situation does suggest that the conversion is limited in relation to the high demand for growth. If the pre-term infant had remained as a foetus it would have benefited from the selection of AA by the placenta. At the same time, the return of linoleic acid to the maternal cir-

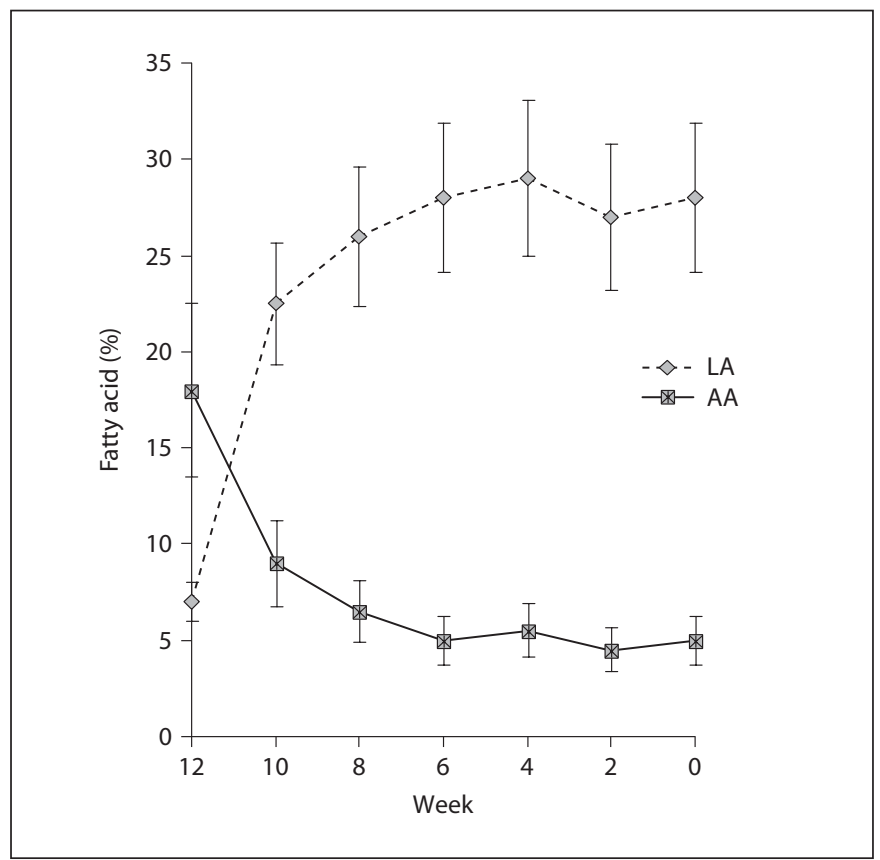

Fig. 3. Data from birth questions the idea that the preterm infant can efficiently convert linoleic acid (LA) to AA. Postnatally AA drops in the plasma choline phosphoglycerides to a third of the birth (intrauterine) level despite its precursor LA rising 3- to 4fold. Data from 12 weeks preterm to expected date of delivery 0 . After Leaf et al. [1992].

culation leaves a physiological message preferring the use of AA preformed during early development.

The known functions of AA in the brain involve production of eicosanoids, endocannabinoids, activation of protein kinase $\mathrm{C}$ and its intimate involvement in peroxisome proliferator-activated receptors, inositol phosphoglyceride signalling as well as several other signalling pathways and as mentioned above, in resolution of injury and inflammation. With the adverse publicity focussed on AA, the research has been one-sided and there may be other positive functions yet to be discovered.

There is a need for further research on the functions of dihomo- $\gamma$-linolenic, AA and docosatetraenoic acid $(22: 4 n-6)$ in the brain, vascular and immune systems.

\section{Daily Consumption of AA and DHA by the Adult Human Brain}

Rapoport et al. [2007] have reported studies on $1{ }^{11} \mathrm{C}$ labelled AA and DHA in adult humans. They have calculated the incorporation rates of the labelled free fatty 
acid as $17.8 \mathrm{mg} /$ day/1,500 g brain for AA and $4.6 \mathrm{mg} /$ day/ $1,500 \mathrm{~g}$ brain for DHA. Based on an estimation of the AA and DHA content of human brains, they calculated the brain half-life of AA at 147 days and that of DHA at 773 days (2.5 years). While this half-life seems to be quite long, further calculations by this group suggested that the brain DHA would fall by $5 \%$ if DHA disappeared from the plasma for only 41 days.

The functional consequences of such a decline are unknown at this stage. What is not known is the dietary intake of PUFA required to supply AA and DHA at levels to maintain the turnover of these PUFA in this tissue. Every other tissue in the body will have a demand for AA and DHA, with DHA specifically in demand by mitochondria, the testes and spermatozoa, whilst the vascular endothelium, immune cells, muscle and platelets have a substantial requirement for both AA and DHA.

Studies are lacking in humans on the uptake of AA and DHA from phospholipids in plasma, though earlier research by Lagarde et al. [2001] in rats suggested that lysophosphatidylcholine may be a preferred carrier of DHA for the brain.

\section{Depression and Bipolar Disorder}

This section discusses the epidemiological data associating long-chain n-3 PUFA intakes with depression and the results of intervention trials of long-chain n-3 PUFA in treating depression and bipolar disorder. Over the past few years, there have also been a substantial number of reviews published on this topic [Freeman et al., 2006; Parker et al., 2006; Sinclair et al., 2007; Appleton et al., 2008].

\section{Epidemiology}

Three ecological studies on seafood consumption, major depression and post-partum depression report that seafood consumption was correlated with lower rates of depression, post-partum depression or bipolar disorders in relationships that were highly statistically significant [Hibbeln, 1998, 2002; Noaghiul and Hibbeln, 2003].

Ten studies have analysed serum/plasma, red blood cell, adipose and even brain long-chain n-3 PUFA levels in subjects of all ages with depression. The number of participants studied ranged from 24 to 3,884 . All studies reported lower long-chain n-3 PUFA levels in the subjects with depression (in some studies, the ratios of AA/
EPA or the ratio of the n- 6 to n-3 PUFA were higher in depression).

Two studies considered patients who had experienced myocardial infarction. In the first study, of 50 patients, the depressed subjects had higher serum levels of AA/ EPA [Schins et al., 2007]. In the second study, which involved 812 subjects, depressed subjects had significantly lower plasma concentrations of total n-3 and DHA [Frasure-Smith et al., 2004]. In a study of post-mortem brain tissue, it was found that DHA was the only fatty acid that was significantly lower in the orbitofrontal cortex of the individuals with major depressive disorder, and that such deficits in DHA were greater in female than male patients [McNamara et al., 2007].

Two cohort studies examined the relationship between intakes of n-3 PUFA and depression. In 1 cohort study of 29,133 subjects from Finland, the $n-3$ intake was assessed by a food frequency questionnaire related to the diet over the previous 12 months, and the outcome measures were self-reported depressed mood, hospital treatment due to depressed mood or death from suicide. It was found that neither n-3 nor fish intake were associated with depressed mood [Hakkarainen et al., 2004]. In the second study, of 7,903 subjects from the USA, the n-3 and fish intakes were assessed by a semi-quantitative food frequency questionnaire, and the outcome measures were incident mental disorder defined as a self-reported physician diagnosis of depression, anxiety or stress and/or use of antidepressant medication or tranquilisers. Subjects with moderate fish consumption (third and fourth quintiles of consumption, amounting to median fish intakes of 83.3 and $112 \mathrm{~g}$ /day) had a relative risk reduction of greater than 30\% [Sanchez-Villegas et al., 2007].

Six cross-sectional studies have examined the relationship between intakes of $n-3$ PUFA and depression. These studies, which had large subject numbers (range $755-21,835$ ), relied on the use of food frequency questionnaires to determine $\mathrm{n}-3$ or fish intakes. The outcome measures included the Beck Depression Inventory and the Hospital Anxiety and Depression Scale. The results were consistent in 5 of the 6 studies; that is, the greater the fish/fish oil intake the less likely the subjects were to have depressive symptoms [Tanskanen et al., 2001; Silvers and Scott, 2002; Suzuki et al., 2004; Timonen et al., 2004; Raeder et al., 2007]. The negative study of 755 women used a self-report questionnaire based on DSM-IV criteria to determine 12-month prevalence rates of depression and a biennial food frequency questionnaire for seafood and fish oil consumption over a 6-year period [Jacka et al., 2004]. 
Table 1. Intervention studies using long-chain n-3 PUFA in depression

\begin{tabular}{|c|c|c|c|}
\hline Authors & Subjects, $\mathrm{n}$ & Treatment & Outcome \\
\hline $\begin{array}{l}\text { Peet and } \\
\text { Horrobin, } 2002\end{array}$ & $\begin{array}{l}\text { Placebo: } 18 \\
\text { Treatment 1: } 17 \\
\text { Treatment 2: } 18\end{array}$ & $1 \mathrm{~g}$ E-EPA for 12 weeks; adjunctive therapy & $\begin{array}{l}\text { Supplementation with } 1 \mathrm{~g} / \text { day clearly } \\
\text { reduced depression severity }\end{array}$ \\
\hline $\begin{array}{l}\text { Nemets } \\
\text { et al., } 2002\end{array}$ & $\begin{array}{l}\text { Placebo: } 10 \\
\text { Treatment: } 10\end{array}$ & $2 \mathrm{~g}$ E-EPA for 4 weeks; adjunctive therapy & $\begin{array}{l}\text { Clinically relevant reduction in symptoms } \\
\text { on the HDRS scores }\end{array}$ \\
\hline $\begin{array}{l}\text { Su } \\
\text { et al., } 2003\end{array}$ & $\begin{array}{l}\text { Placebo: } 11 \\
\text { Treatment: } 11\end{array}$ & $\begin{array}{l}2.2 \mathrm{~g} \text { EPA }+1.1 \mathrm{~g} \text { DHA for } 8 \text { weeks; } \\
\text { adjunctive therapy }\end{array}$ & $\begin{array}{l}\text { Intervention group showed significantly } \\
\text { reduced HDRS scores }\end{array}$ \\
\hline $\begin{array}{l}\text { Nemets } \\
\text { et al., } 2006\end{array}$ & $\begin{array}{l}\text { Placebo: } 10 \\
\text { Treatment: } 10\end{array}$ & $\begin{array}{l}0.4 \mathrm{~g} \text { EPA }+0.2 \mathrm{~g} \text { DHA for } 16 \text { weeks; } \\
\text { monotherapy (in children) }\end{array}$ & $\begin{array}{l}\text { Significantly reduced scores in CDRS, } \\
\text { CDI, and CGI }\end{array}$ \\
\hline $\begin{array}{l}\text { Marangell } \\
\text { et al., } 2003\end{array}$ & $\begin{array}{l}\text { Placebo: } 17 \\
\text { Treatment: } 18\end{array}$ & 2 g DHA for 6 weeks; monotherapy & $\begin{array}{l}\text { Treatment outcomes not significantly } \\
\text { different to placebo }\end{array}$ \\
\hline $\begin{array}{l}\text { Silvers } \\
\text { et al., } 2005\end{array}$ & $\begin{array}{l}\text { Placebo: } 37 \\
\text { Treatment: } 40\end{array}$ & $\begin{array}{l}0.6 \mathrm{~g} \text { EPA }+2.4 \mathrm{~g} \text { DHA for } 12 \text { weeks; } \\
\text { adjunctive therapy }\end{array}$ & $\begin{array}{l}\text { Treatment outcomes not significantly } \\
\text { different to placebo }\end{array}$ \\
\hline $\begin{array}{l}\text { Grenyer } \\
\text { et al., } 2007\end{array}$ & $\begin{array}{l}\text { Placebo: } 10 \\
\text { Treatment: } 10\end{array}$ & $\begin{array}{l}0.6 \mathrm{~g} \text { EPA }+2.2 \mathrm{~g} \mathrm{DHA} \text { for } 16 \text { weeks; } \\
\text { adjunctive therapy }\end{array}$ & $\begin{array}{l}\text { Treatment outcomes not significantly } \\
\text { different to placebo }\end{array}$ \\
\hline $\begin{array}{l}\text { Stoll } \\
\text { et al., } 1999 b\end{array}$ & $\begin{array}{l}\text { Bipolar } \\
\text { Placebo: } 16 \\
\text { Treatment: } 14\end{array}$ & $\begin{array}{l}6.2 \mathrm{~g} \mathrm{EPA}+3.4 \mathrm{~g} \text { DHA for } 16 \text { weeks; } \\
\text { adjunctive therapy }\end{array}$ & $\begin{array}{l}\text { Treatment group showed amelioration of } \\
\text { depressive symptoms }\end{array}$ \\
\hline $\begin{array}{l}\text { Frangou } \\
\text { et al., } 2006\end{array}$ & $\begin{array}{l}\text { Bipolar } \\
\text { Placebo: } 26 \\
\text { Treatment 1: } 24 \\
\text { Treatment 2: } 25\end{array}$ & $\begin{array}{l}1 \text { or } 2 \mathrm{~g} \text { E-EPA for } 12 \text { weeks, not significantly } \\
\text { different to placebo; adjunctive therapy }\end{array}$ & $\begin{array}{l}\text { Results for treatment group not different } \\
\text { to placebo }\end{array}$ \\
\hline $\begin{array}{l}\text { Keck } \\
\text { et al., } 2006\end{array}$ & $\begin{array}{l}\text { Bipolar } \\
\text { Placebo 1: } 28 \\
\text { Placebo 2: } 29 \\
\text { Treatment 1: } 28 \\
\text { Treatment 2: } 31\end{array}$ & $\begin{array}{l}6 \mathrm{~g} \text { E-EPA for } 16 \text { weeks, not significantly } \\
\text { different to placebo; adjunctive therapy }\end{array}$ & $\begin{array}{l}\text { No benefit for individuals in treatment } \\
\text { group }\end{array}$ \\
\hline $\begin{array}{l}\text { Frangou } \\
\text { et al., } 2007\end{array}$ & $\begin{array}{l}\text { Bipolar } \\
\text { Placebo: } 7 \\
\text { Treatment: } 7\end{array}$ & $2 \mathrm{~g}$ E-EPA for 12 weeks; adjunctive therapy & $\begin{array}{l}\text { Results for treatment group not different } \\
\text { to placebo }\end{array}$ \\
\hline $\begin{array}{l}\text { Osher } \\
\text { et al., } 2005\end{array}$ & $\begin{array}{l}\text { Bipolar } \\
\text { Treatment: } 12\end{array}$ & $\begin{array}{l}1.5-2 \mathrm{~g} \text { E-EPA for } 24 \text { weeks, positive; } \\
\text { adjunctive therapy }\end{array}$ & $\begin{array}{l}\text { Positive outcome in open-label design } \\
\text { study }\end{array}$ \\
\hline
\end{tabular}

CDI = Children's Depression Inventory scale; CDRS = Children's Depression Rating Scale; CGI = Clinical Global Impression; HDRS = Hamilton Depression Rating Scale.

\section{Intervention Studies}

The 12 studies reviewed are listed in table 1.

\section{Major Depressive Disorder}

Peet and Horrobin [2002] carried out the first placebocontrolled double blind study examining the effects of ethyl-EPA (E-EPA) supplementation as an adjunct to an- tidepressant medication in 70 treatment-resistant patients with major depressive disorder. They administered 1,2 , and $4 \mathrm{~g} /$ day of E-EPA or a liquid paraffin placebo for 12 weeks, and utilised the HDRS (Hamilton Depression Rating Scale) as the primary outcome measure, with scores on the Beck Depression Inventory and MADRS (Montgomery-Asberg Depression Rating Scale) as secondary outcomes. Supplementation with $1 \mathrm{~g}$ /day E-EPA 
(but not 2 or $4 \mathrm{~g} /$ day) demonstrated clearly reduced depression severity on each outcome measure compared with placebo, even from the first time point recorded (4 weeks), leading to large and significant differences in selfrated depression, anxiety, sleep, lassitude, libido and suicidal ideation. The only other study to date that has utilised E-EPA in addition to standard antidepressant medication supplemented $2 \mathrm{~g}$ /day of E-EPA to 20 participants for 4 weeks and demonstrated significant effects compared with placebo [Nemets et al., 2002]. The group receiving E-EPA showed a clinically relevant reduction in symptoms on the HDRS characterised by significantly reduced insomnia, depressed mood and feelings of guilt and worthlessness. These 2 studies demonstrated a lack of significant clinical side effects arising from $n-3$ supplementation. An apparent antidepressant effect of n-3 PUFA was also demonstrated by Su et al. [2003] who supplemented the medication of 22 depressed individuals for 8 weeks with EPA + DHA (2.2 g EPA and $1.1 \mathrm{~g} \mathrm{DHA}$ ) or an olive oil placebo. After 4 weeks of supplementation, patients in the intervention group exhibited significantly reduced HDRS scores compared with placebo. Interestingly, this study utilised orange flavouring to disguise the taste of the fish oil capsules.

One study in children, where long-chain n-3 PUFA was used as monotherapy in childhood depression, has been reported. Nemets et al. [2006] and colleagues administered $0.4 \mathrm{~g}$ EPA and $0.2 \mathrm{~g}$ DHA or a safflower oil placebo to 20 children for 16 weeks. The children in the treatment group demonstrated significantly reduced scores on the Children's Depression Rating Scale, Children's Depression Inventory, and Clinical Global Impression (CGI), with changes evident after 8 weeks of supplementation.

Three randomised controlled trials (RCT) have explored the effect of administering supplements containing primarily DHA to patients being treated for a current depressive episode. In the first study, 18 participants were administered $2 \mathrm{~g}$ of DHA daily as a monotherapy for 6 weeks, and statistically significant differences in MADRS or HDRS scores were not found compared with placebo [Marangell et al., 2003]. Similarly, Silvers et al. [2005] supplemented the diets of 77 individuals with fish oil capsules containing $2.4 \mathrm{~g}$ DHA and $0.6 \mathrm{~g}$ EPA for 12 weeks and again did not obtain evidence that supplementation improved mood. A significant flaw with this particular study is that inclusion into the study was dependent on self-reported depression symptoms as determined by the HDRS, as opposed to the clinical interviews based on the DSM-IV criteria endorsed by the other trials discussed.
A consequence of this was that the participants in the study had considerably fewer depression symptoms at baseline, and at the conclusion of the study, none of the participants had any remaining depression symptomatology, which indicates that perhaps the participants were not clinically depressed. Recently, Grenyer et al [2007] administered long-chain n-3 PUFA (2.2 g DHA and $0.6 \mathrm{~g} \mathrm{EPA}$ ) or an olive oil placebo to 83 depressed outpatients as an adjunct to conventional treatment for 16 weeks. Despite excellent compliance, there were no differences in HDRS or Beck Depression Inventory scores between the groups, nor were there any differences in personal, occupational or interpersonal functioning.

\section{Bipolar Disorder}

Five studies have explored the effect of n-3 PUFA supplementation on individuals with bipolar disorder. The first, conducted by Stoll et al. [1999a, 1999b], administered $6.2 \mathrm{~g} \mathrm{EPA}$ and $3.4 \mathrm{~g}$ DHA daily to 30 participants for 16 weeks. The treatment group demonstrated an amelioration of depressive symptoms (using the HDRS, CGI and Global Assessment Scale), and a Kaplan-Meier survival analysis indicated that the $\mathrm{n}-3$ fatty acid-treated patient group had a significantly longer period of symptom remission than the placebo group. In another study using a relatively small number of patients and an open-label design, E-EPA treatment also had a positive outcome. Specifically, 12 bipolar I outpatients with depressive symptoms diagnosed according to DSM-IV criteria were treated with 1.5-2 g/day of E-EPA for up to 6 months. Eight of the 10 patients who completed at least 1 month of followup achieved a $50 \%$ or greater reduction in HDRS scores, and none of the participants developed hypomania or manic symptoms [Osher et al., 2005]. This study was limited by both its open-label design and small sample size.

A further study attempted to confirm the results of the Stoll study [Stoll et al., 1996] by administering 6 g/day E-EPA or placebo as an adjunct to mood stabilising medications to 116 bipolar individuals for 16 weeks. The outcome measures in the study were the Young Mania Rating Scale, Inventory of Depressive Symptomatology, and Clinical Global Impression Scale-Bipolar Disorder (CGI$\mathrm{BP})$; however, the results indicated no benefit for individuals in the treatment group compared with placebo [Keck et al., 2006].

Frangou and colleagues [2006] examined the efficacy of E-EPA as an adjunctive therapy in 75 outpatients with bipolar depression. The participants were randomly assigned to receive adjunctive treatment with $1 \mathrm{~g} /$ day of E-EPA $(n=24), 2$ g/day of E-EPA $(n=25)$ or liquid paraf- 
fin placebo $(\mathrm{n}=26)$ for 12 weeks. HDRS and CGI scores decreased in both of the treatment groups; however, the results were not significantly different from placebo. The same group investigated further the mechanism by which E-EPA works in the brain of individuals with bipolar disorder [Frangou et al., 2007]. Fourteen participants were administered $2 \mathrm{~g}$ E-EPA or liquid paraffin placebo per day for 12 weeks. Quantitative proton magnetic resonance spectroscopy images were obtained prior to and following 12 weeks of treatment, from a $12 \mathrm{ml}$ volume of interest above the corpus callosum. A significant rise in brain levels of $\mathrm{N}$-acetyl-aspartate, a putative marker of neuronal integrity, was observed in participants in the treatment condition compared with the placebo group; however, there were no differences between the groups on the HDRS.

\section{Mechanisms}

Several neurophysiological mechanisms have been proposed to explain the relationship between n-3 PUFA and depression.

The most commonly suggested effect is on eicosanoid production. This is because EPA and DHA, as well as the mood stabilising drugs commonly used to treat bipolar disorder (lithium, carbamazepine and valproic acid) [Bosetti et al., 2003; Bazinet et al., 2006; Basselin et al., 2007], interfere with the AA cascade, including competitively inhibiting COX and thus decreasing production of the 2series prostaglandins.

Other proposed mechanisms include effects on downstream functions, including cytokine expression ( $n-3$ PUFA inhibit expression of IL-1, IL-6, IL-8, TNF- $\alpha$ and IFN- $\gamma$ ] [De Caterina et al., 1994; Maes et al., 1995; Kelley et al., 1999; Raison et al., 2006] and neurotransmitter release (serotonergic and dopaminergic neurotransmission is enhanced by long-chain n-3 PUFA) [Chalon et al., 1998; Zimmer et al., 2002; Kodas et al., 2004].

In addition, cAMP response element-binding protein and BDNF have been implicated, as n-3 PUFA increase BDNF by suppressing pro-inflammatory cytokines thus triggering a cAMP cascade, leading to expression of cAMP response element binding protein and BDNF [Nibuya et al., 1995; Mamounas et al., 2000; Chen et al., 2001; Shimizu et al., 2003; Beltz et al., 2007; Rao et al., 2007b].

Furthermore, it has been identified that increased cerebral blood flow [Katsumata et al., 1999] and enhanced vascular reactivity [Abeywardena and Head, 2001] occur following n-3 PUFA supplementation, which is important as both of these are down-regulated in depressed individuals [Ellis et al., 1992; Liotti et al., 2002; Neu et al., 2004; Conway et al., 2006].

Fat Intake and CNS Functioning:

Ageing and Disease
The brain contains very low levels of EPA compared with DHA [Crawford et al., 1976], yet of all the studies conducted, those using EPA have shown the most consistent benefits. It is possible that EPA exerts some of its effects in mood disorders by improving blood flow and therefore supplying the brain with nutrients such as glucose. This EPA effect could be mediated by the endothelial cells in the extensive blood vessel architecture of the brain. Other studies have shown an increase in EPA levels in endothelial cells following supplementation and this leads to improved vascular function [Chisaki et al., 2003; Conway et al., 2006; Walser et al., 2006; Wan et al., 2007].

An interesting new concept arises from the work of Holmsen and his colleagues at Bergen University. Chlorpromazine is a cationic, amphiphilic psychotropic drug of the phenothiazine group that was the first drug used to treat schizophrenia and other psychiatric disease, and is still used in therapy. They have produced strong molecular evidence using solid-state magic angle spinning ${ }^{13} \mathrm{C}-\mathrm{NMR}$, demonstrating the drug interacts not with proteins of the receptor but with the brain phosphatidylserine. Further studies with pure 18:0/22:6n-3-phosphatidylserine showed that chlorpromazine reduced the mobility of the $\mathrm{C} 4$ and $\mathrm{C} 5$ atoms in DHA, which are attached to each other with a double bond [Chen et al., 2005].

All psychotropic drugs distribute between membranes and water with distribution coefficients in the range of 10,000-20,000 [for references, see Oruch et al., 2008]. This suggests that the drugs will enter the membranes through the outer leaflet, diffuse through the acyl layer and are able to interact with the phosphatidylserine in the inner leaflet. One would assume that the structural changes caused will affect the positioning of the proteins, such as membrane-bound enzymes and receptors, and thereby alter their functions. Thus, in addition to acting as antagonists for receptors, the drugs may also alter membrane protein activities. Conversely, this evidence provides a mechanism whereby diet could affect key receptors and transporters related to psychosis simply by manipulating the physical chemistry of the surrounding domain.

This explanation for the long-chain n-3 PUFA effect on the brain does not fit with the idea of EPA having a stronger effect than DHA, except if the EPA is influencing blood vessel function or having an effect on the brain that has not yet been described. Clearly, there is a great deal that needs to be known before definite conclusions can be drawn.

The studies which support this distinction between EPA and DHA are few, and there are problems with the design, mainly related to the duration, dose and fatty acid

Ann Nutr Metab 2009;55:202-228 
control. A further criticism relates to the controls in EFA trials when it comes to claims regarding the effect of $n-3$ versus n-6 fatty acids. Various controls have been used with the placebos of olive oil or even liquid paraffin. Specific claims may be made for a specific effect of EPA compared to $n-6$ PUFA. The validity is questionable if, for example, linoleic acid is used as representing the $n-6$ family to compare with the n-3, EPA- and/or DHA-rich oils. As the properties of the 18,20 and 22 carbon chain length are quite clearly different, it may be more scientific to compare like with like by, for example, comparing AA with EPA.

The criticism of the short nature of most studies in depression/bipolar disorder, and possibly of all studies in this area, is perhaps best highlighted by comparing them with the GISSI (the Italian Group for the Study of the Survival of Myocardial Infarction) n-3 PUFA intervention in heart disease. Such studies were planned for a 5-year time frame and although a significant protective effect emerged in the first year, the time scales of the neuropsychiatric studies with EPA and DHA for the most part are performed within the time scale during which no result was seen in the GISSI trial.

\section{Conclusions on Depression}

This section has outlined epidemiological and intervention studies conducted in depression using long-chain n-3 PUFA. The epidemiological studies generally, but not in all instances, supported a benefit of consumption of long-chain n-3 PUFA in mood disorders. Some might argue that eating higher amounts of fish is associated with other healthy lifestyle behaviours (food quality and variety, exercise patterns, etc.) and this should be considered as a potential confounding factor in studies of this nature. The intervention studies have been extremely heterogeneous, often with small sample sizes. The subjects have varied in the severity of depression, the use of n-3 PUFA as monotherapy or adjunct therapy, the type of long-chain n-3 PUFA (fish oil containing EPA + DHA, DHA from algal oil or purified E-EPA), the dose of longchain n-3 PUFA and the duration of the intervention. To date, there has not been an adequate dose-response study. There are several proposed mechanisms for the benefits of the n-3 PUFA.

It is interesting that the majority of the studies conducted to date have utilised long-chain n-3 PUFA as adjunctive therapy to traditional antidepressants and mood stabilisers. Given that a number of the studies in which EPA was supplemented as an adjunct treatment demonstrated increased symptom remission, it is possible that EPA operates in a synergistic fashion with the mood medications. One promising theory is that EPA enhances endothelial cell function in blood vessels, which has the effect of increasing cerebral blood flow, thus EPA may augment the effects of the antidepressants which are known to act on other mechanisms, including involving monoaminergic neurotransmitters (serotonin and noradrenalin) [Gardier, 2005].

While research indicates that orally administered DHA is rapidly incorporated into neural tissue [Sinclair, 1975], no studies have been reported on the uptake of other long-chain n-3 PUFA (EPA and docosapentaenoic acid, 22:5n-3) into neural endothelial blood vessels or brain cells.

In summary, future research in this area should involve studies with purified preparations of long-chain n-3 PUFA (alone and in combination), relevant controls (which has often not been the case), dose-response studies, studies on the duration of supplementation required for greatest benefit, larger numbers of subjects in each treatment group, studies to delineate the importance of n-3 PUFA as monotherapy or adjunct therapy and studies which identify the mechanism(s) of action of these PUFA in mood disorders.

\section{Cognition}

In view of the increasing interest in the role of $n-3$ PUFA and brain function, especially in relation to ageing, this section considers the relationship between n-3 PUFA intake or status (circulating levels) and cognition. In general terms, the subjects taking part in relevant studies were of normal age and tested with a battery of cognitive function tests. The search terms we used to find relevant studies were ' $n-3$ ', 'DHA', 'EPA' linked with 'mood' and with 'cognition'. This approach identified most of the studies referred to above on depression, some studies in schizophrenic subjects, some studies related to Alzheimer's disease and 13 studies relevant to mood and cognition (table 2). To summarise these studies, 3 were intervention (number of subjects studied ranged from 21 to 218 ) and 11 were observational (number of subjects studied ranged from 15 to approximately 8,000). Two of the intervention studies were negative, and 1 found some benefit. Of the observational studies, all found a positive association between n-3 intake/status and improved mood/cognition.

This literature reveals that there is limited evidence to support the relationship between n-3 PUFA intakes and altered mood/cognition though there is significant sup- 
Table 2. Studies on n-3 PUFA and cognition in adults

\begin{tabular}{|c|c|c|}
\hline Authors & Number of subjects and treatment & Outcome \\
\hline $\begin{array}{l}\text { Rogers } \\
\text { et al., } 2008\end{array}$ & $\begin{array}{l}\mathrm{n}=218 ; 1.5 \mathrm{~g} / \text { day of } \mathrm{EPA}+\mathrm{DHA} \\
12 \text { weeks }\end{array}$ & $\begin{array}{l}\text { No effect of long-chain n-3 PUFA (EPA and DHA) supplementation on } \\
\text { depressed mood and cognitive function (RCT) }\end{array}$ \\
\hline $\begin{array}{l}\text { Kotani } \\
\text { et al., } 2006\end{array}$ & $\begin{array}{l}\mathrm{n}=21 ; 240 \mathrm{mg} / \text { day of each of AA } \\
\text { or DHA }\end{array}$ & $\begin{array}{l}\text { Dietary supplementation of AA and DHA can improve cognitive dys- } \\
\text { function due to organic brain damage or ageing }\end{array}$ \\
\hline $\begin{array}{l}\text { Whalley } \\
\text { et al., } 2008\end{array}$ & $\mathrm{n}=120$; aged at least 64 years & $\begin{array}{l}\text { Cognitive benefits were associated with higher } \mathrm{n}-3 \text { fatty acid erythrocyte } \\
\text { membrane content, but only in the absence of APOE } \varepsilon 4 \text { allele }\end{array}$ \\
\hline $\begin{array}{l}\text { Dullemeijer } \\
\text { et al., } 2007\end{array}$ & $\mathrm{n}=807$ & $\begin{array}{l}\text { Higher } n-3 \text { fatty acid proportions in plasma predicted less cognitive } \\
\text { decline in some tests of performance in older adults }\end{array}$ \\
\hline $\begin{array}{l}\text { Beydoun } \\
\text { et al., } 2008\end{array}$ & $\mathrm{n}=>10,000$ & $\begin{array}{l}\text { Increased dietary long-chain n-3 fatty acids associated with decreased } \\
\text { risk of } 6 \text {-year cognitive decline in verbal fluency in older adults with } \\
\text { hypertension }\end{array}$ \\
\hline $\begin{array}{l}\text { Beydoun } \\
\text { et al., } 2007\end{array}$ & $\mathrm{n}=2,251$ & $\begin{array}{l}\text { Higher plasma n-3 fatty acids had a reduced risk of cognitive decline } \\
\text { (verbal fluency) in older adults with hypertension and dyslipidaemia }\end{array}$ \\
\hline $\begin{array}{l}\text { Whalley } \\
\text { et al., } 2004\end{array}$ & $\mathrm{n}=120$ & $\begin{array}{l}\text { Food supplement use and red cell } n-3 \text { content associated with better } \\
\text { cognitive ageing }\end{array}$ \\
\hline $\begin{array}{l}\text { Kalmijn } \\
\text { et al., } 2004\end{array}$ & $\mathrm{n}=1,613 ; \mathrm{FFQ}$ & $\begin{array}{l}\text { Dietary intake of fatty acids and fish associated with reduced risk of } \\
\text { impaired cognitive function }\end{array}$ \\
\hline $\begin{array}{l}\text { Heude } \\
\text { et al., } 2003\end{array}$ & $\mathrm{n}=246$ & $\begin{array}{l}\text { Inverse association between cognitive decline and proportion of long- } \\
\text { chain } n-3 \text { fatty acids in erythrocyte membranes }\end{array}$ \\
\hline $\begin{array}{l}\text { Conklin } \\
\text { et al., } 2007\end{array}$ & $\mathrm{n}=105$ & $\begin{array}{l}\text { Serum n-3 fatty acid status was associated with reduced risk of a high } \\
\text { score on a standard depression index in hypercholesterolemic commu- } \\
\text { nity volunteers }\end{array}$ \\
\hline $\begin{array}{l}\text { McNamara } \\
\text { et al., } 2007\end{array}$ & $\mathrm{n}=15$ with MDD; $\mathrm{n}=27$ control & $\begin{array}{l}\text { Selective deficits in the } \mathrm{n}-3 \text { fatty acid DHA in the postmortem orbito- } \\
\text { frontal cortex of patients with major depressive disorder }\end{array}$ \\
\hline $\begin{array}{l}\text { Schaefer } \\
\text { et al., } 2006\end{array}$ & $\mathrm{n}=899 ;$ followed for 9.1 years & $\begin{array}{l}\text { The top quartile of plasma phosphatidylcholine DHA content was } \\
\text { associated with a significant reduction in risk of dementia in the Fram- } \\
\text { ingham Heart Study }\end{array}$ \\
\hline $\begin{array}{l}\text { Assisi } \\
\text { et al., } 2006\end{array}$ & A review paper & $\begin{array}{l}\text { Fish oil and mental health: the role of long-chain n-3 PUFAs in cognitive } \\
\text { development and neurological disorders }\end{array}$ \\
\hline $\begin{array}{l}\text { Freund-Levi } \\
\text { et al., } 2006\end{array}$ & $\begin{array}{l}\mathrm{n}=204 ; 1.7 \mathrm{~g} \text { DHA }+0.6 \mathrm{~g} \text { EPA/day } \\
\text { for } 6 \text { months }+6 \text { months }\end{array}$ & $\begin{array}{l}\mathrm{n}-3 \text { fatty acid treatment in patients with mild to moderate } \mathrm{AD} \text { did not } \\
\text { delay the decline in } \mathrm{AD} \text {. A positive effect was noted in a small group with } \\
\text { very mild } \mathrm{AD}\end{array}$ \\
\hline $\begin{array}{l}\text { Barberger-Gateau } \\
\text { et al., } 2007\end{array}$ & $\mathrm{n}=8085 ;$ dietary patterns & $\begin{array}{l}\text { Frequent consumption of fruits and vegetables, fish and n-3 oils may } \\
\text { decrease risk of dementia and } \mathrm{AD} \text {, especially among APOE } \varepsilon 4 \\
\text { non-carriers }\end{array}$ \\
\hline
\end{tabular}

$\mathrm{AD}=$ Alzheimer's disease; $\mathrm{APOE}=$ apolipoprotein; $\mathrm{FFQ}=$ food frequency questionnaire; $\mathrm{MDD}=$ major depressive disorder.

port from observational studies to conduct thorough intervention studies in appropriate subjects using sufficiently sensitive tests designed to measure effects on cognition.

It is worth noting that the study by Kotani et al. [2006] reported that supplementation of a small number of adults, who had mild cognitive dysfunction, with AA and DHA (240 mg/day of each) resulted in an improvement in short-term memory retention and attention.

In summary, there is limited evidence to support the relationship between n-3 PUFA intake/status and altered cognition although there is significant support from ob- 
servational studies to justify thorough intervention studies in appropriate subjects using sufficiently sensitive tests designed to measure effects in cognition.

\section{Aggression, Hostility and Anti-Social Behaviour}

This area has been reviewed by Appleton et al. [2008] and the details of the studies are reported in table 5 of that paper. These authors reported there was 1 epidemiological study, conducted among 3,581 young adults, that found negative associations between hostility and the DHA content of the diet [Iribarren et al., 2004].

Three studies investigated the relationship between n-3 status and aggressive or violent behaviour. One study found lower DHA status in aggressive versus non-aggressive cocaine dependents [Buydens-Branchey and Branchey, 2006]. Neither of the other 2 studies found differences between violent and non-violent controls or between individuals with intermittent explosive disorder and controls [Virkkunen et al., 1987; Umhau et al., 2006]. Twelve placebo-controlled studies were identified investigating effects of $\mathrm{n}-3$ supplementation on aggression, anger, hostility, tension, irritability and anti-social behaviour. Two studies found decreases in aggression after n-3 treatment (E-EPA or EPA + DHA) [Hamazaki et al., 2002; Zanarini and Frankenburg, 2003], and 1 study found decreases in tension after treatment with EPA + DHA [Fontani et al., 2005]. Of considerable significance to the community was the study reported by Gesch et al. [2002]. They found a decrease in anti-social behaviour, including violence, after treatment of young prisoners with a complex mix of nutrients including EPA + DHA + n-6 PUFA + vitamins and minerals [Gesch et al., 2002]. This study was in 231 prisoners, and the outcome measure was the number of offences. This study has attracted much attention in the press and elsewhere. Two studies reported increases in aggression in the placebo, but no change in the treated groups (EPA + DHA) [Hamazaki et al., 1996; Itomura et al., 2005]. The remaining studies did not report any benefits from treatment with the active compounds (mostly EPA + DHA) [Appleton et al., 2008].

In summary, the results of epidemiological and intervention studies with long-chain n-3 PUFA have been equivocal. The study populations have been heterogeneous, sometimes with only a small number of subjects. Despite this, there are some encouraging data emerging in treatment of violence among prisoners, and this is clearly an area where more research is required in defined populations with larger numbers of subjects.

\section{Fat Intake and Age-Related Maculopathy}

Age-related maculopathy (ARM) is the leading cause of blindness in industrialised countries, representing $50 \%$ of all cases of blindness in these countries [Resnikoff et al., 2004]. This disease affects the visual centre of the retina (called macula) [Jager et al., 2008]. The early phase of the disease, usually asymptomatic, is characterised by the presence of drusen (accumulation of extracellular material seen as yellow spots on the retina on ophthalmoscopic examination) and/or of pigmentary abnormalities (areas of hyper- and/or hypo-pigmentation). The late stage is characterised by the presence of geographic atrophy (disappearance of the neuroretinal tissue) or of choroidal neovascularisation (neovascular ARM). Neovascular ARM is the major cause of severe visual loss.

ARM is currently thought to result from gene-environment interactions. Indeed, several gene polymorphisms are strongly associated with an increased risk for ARM [Scholl et al., 2007; Yates et al., 2007]. Most of them belong to the alternative pathway of the complement (complement factors $\mathrm{H}, \mathrm{B}, \mathrm{C} 3$ ), suggesting an important role of inflammation in ARM. Subjects bearing the apolipoprotein $\mathrm{E} 4$ allele have also been shown to have a reduced risk for ARM, suggesting a role of lipid metabolism in ARM [Friedman et al., 2007]. With regard to environmental factors, smoking is now considered as a causal factor, while nutritional factors receive increasing interest [Jager et al., 2008].

Diet has already been identified as an important modifiable risk factor and the management of age-related macular degeneration (AMD) has been influenced by evidence from the Age-Related Eye Disease Study (AREDS) which demonstrated that a high-dose zinc and antioxidant vitamin supplement (vitamin C, E and $\beta$-carotene) slowed AMD progression by around $25 \%$ in relatively advanced ARM stages [AREDS, 2001]. Dietary fatty acids are another important potential dietary factor worthy of investigation. Dietary fatty acids may be related to AMD development through their effect on atherosclerosis and their presence in retinal and macular cells.

Among nutritional factors, long-chain $\mathrm{n}-3$ fatty acids (DHA and EPA) may be protective against ARM [SanGiovanni and Chew, 2005]. Indeed, DHA is a major component of the retina, representing $50 \%$ of the fatty acids of the outer segments of photoreceptors. Biophysical and biochemical properties of DHA may affect photoreceptor membrane function by altering permeability, fluidity, thickness, and lipid phase properties. Tissue DHA status 
affects retinal cell signalling mechanisms involved in phototransduction. In addition, DHA and EPA probably have anti-angiogenic and anti-inflammatory effects in the retina.

These biological hypotheses are supported by the epidemiology. Although published epidemiological studies remain few, their results are consistent in finding a reduced risk for ARM in regular fish consumers and in subjects with high dietary intakes of long-chain n-3 fatty acids (table 3). Although the associations are not statistically significant in some of the studies, they are always in the same direction and appear to be stronger with fatty fish than with white fish (which has lower content of EPA and DHA). In particular, the 3 population-based prospective studies (in USA, Australia and Iceland) show a statistically significant reduction in risk for incident ARM in subjects with high fish (or herring) intake at baseline [Cho et al., 2001; Arnarsson et al., 2006; Chua et al., 2006]. Two hospital-based clinical prospective studies [Seddon et al., 2003b; SanGiovanni et al., 2008], evaluating progression of ARM in subjects with the early stage of the disease, also suggest a reduction of progression (although not significant in the study by Seddon et al., 2003b).

Recently, a meta-analysis examining the first 9 studies (published before May 2007), including almost 89,000 subjects and 3,203 AMD cases [Chong et al., 2008], estimated a pooled $38 \%$ reduction of risk of late AMD in subjects with high long-chain n-3 fatty acid intake, and a reduction of the risk of early and late ARM in subjects eating fish at least twice a week by 24 and 33\%, respectively. All of these estimates were highly statistically significant.

High intake of the other types of fat (saturated, monounsaturated, n-6 PUFA and ALA) has been associated with an increased risk for ARM, although not consistently between studies [Mares-Perlman et al., 1995; Cho et al., 2001; Seddon et al., 2001, 2003b; Chua et al., 2006; Delcourt et al., 2007; Robman et al., 2007; SanGiovanni et al., 2007]. There is no clear association with each subtype, while high total fat intake may be deleterious for the retina. This is supported by animal models combining human apolipoprotein genes and high fat intake [EspinosaHeidmann et al., 2004; Malek et al., 2005] and by the increased risk of ARM observed in obese subjects [Delcourt et al., 2001; Schaumberg et al., 2001; Seddon et al., 2003a; Clemons et al., 2005].

In conclusion, findings from a range of epidemiological studies and a recent meta-analysis support the hypothesis that an increased dietary intake of long-chain n-3 PUFA and regular fish in the diet protect against the development and progression of AMD. A plausible mech- anism is that long-chain n-3 PUFA promote healthy ocular tissue by regulating inflammatory and immune responses in the retina, thereby reducing the risk of AMD. It may be that the presence of higher $n-6$ fatty acids (mainly linoleic and possibly AA) dampens the effect of n-3 PUFA. Evidence for association between other fatty acid sub-types (monounsaturated and saturated fatty acids) and AMD, however, has been less consistent. In addition to the observational epidemiological studies, it would be valuable to have information from clinical trials about the effect of dietary interventions or supplements with long-chain n-3 PUFA and AMD. Such a study is currently underway with the AREDS trial extension, which will test the role of $n-3$ PUFA supplementation on AMD progression. Findings, however, will not be available for some years [AREDS, 2006].

\section{Alzheimer's Disease}

Alzheimer's disease (AD), the most common dementia among older adults, is a neurodegenerative disease characterised by malfunction or loss of neurons. Although the most common symptom of $\mathrm{AD}$ is memory loss, other mental functions including mood and language can be impaired. The biochemical hallmarks of $\mathrm{AD}$ include neuritic plaques ( $\beta$-amyloid) and neurofibrillary tangles (aggregates of the cytoskeletal protein tau), and other factors, including inflammation, may play a role in disease pathogenesis. Despite putative molecular targets, to date, therapies for $\mathrm{AD}$ target common symptoms as there are no medications that reverse or prevent the progression of $\mathrm{AD}$.

With the development of transgenic cell culture and animal models to study $\beta$-amyloid deposition, initial studies on the role of $n-3$ PUFA in AD were undertaken. Evidence from these and other models suggested that n-3 PUFA supplementation attenuated $\beta$-amyloid deposition, a hallmark of AD [Calon et al., 2004; Lim et al., 2005; Lukiw et al., 2005; Florent et al., 2006; Oksman et al., 2006; Green et al., 2007]. Furthermore, mechanistic studies have demonstrated that along with having antiinflammatory properties [Marcheselli et al., 2003; Rao et al., 2007a; Orr and Bazinet, 2008], DHA promotes neuronal survival via Akt [Akbar et al., 2005], Bcl-2 [Marcheselli et al., 2003] and BDNF [Rao et al., 2007b] signalling pathways. Collectively, these studies, along with postmortem studies, demonstrate lower brain DHA in brains of AD patients [Soderberg et al., 1991; Prasad et al., 1998; Lukiw et al., 2005] and provide mechanistic support for 
Table 3. Epidemiological and clinical studies on the associations of long-chain n-3 PUFA and the risk for ARM

\begin{tabular}{|c|c|c|c|c|c|}
\hline Author, Study & Location & $\begin{array}{l}\text { Population, number } \\
\text { of AMD cases }\end{array}$ & Type & Dietary intake & $\begin{array}{l}\text { Associations } \\
\text { OR (95\% CI) }\end{array}$ \\
\hline $\begin{array}{l}\text { Eye disease } \\
\text { case-control study } \\
\text { [Seddon et al. 2001] }\end{array}$ & USA & $\begin{array}{l}349 \text { cases of NV-ARM, } 504 \\
\text { controls }\end{array}$ & $\begin{array}{l}\text { Case- } \\
\text { control }\end{array}$ & $\mathrm{EPA}+\mathrm{DHA}$ & $0.75(0.44-1.25)$ \\
\hline $\begin{array}{l}\text { AREDS } \\
\text { [SanGiovanni et al., 2007] }\end{array}$ & USA & $\begin{array}{l}657 \text { cases of NV-ARM, 1,115 } \\
\text { controls }\end{array}$ & $\begin{array}{l}\text { Case- } \\
\text { control }\end{array}$ & $\begin{array}{l}\text { Fish } \geq 2 \\
\text { servings/week } \\
\text { EPA + DHA }\end{array}$ & $\begin{array}{l}0.61(0.37-1.00) \\
0.61(0.41-0.90)\end{array}$ \\
\hline $\begin{array}{l}\text { US Twin Study } \\
\text { [Seddon et al., 2006] }\end{array}$ & USA & 681 twins, 222 ARM cases & $\begin{array}{l}\text { Cross- } \\
\text { sectional }\end{array}$ & $\begin{array}{l}\mathrm{EPA}+\mathrm{DHA} \\
\text { Fish } \geq 2 \\
\text { servings/week }\end{array}$ & $\begin{array}{l}0.55(0.32-0.95) \\
0.64(0.41-1.00)\end{array}$ \\
\hline $\begin{array}{l}\text { Beaver } \\
\text { Dam Eye Study } \\
\text { [Mares-Perlman et al., } \\
\text { 1995] }\end{array}$ & USA & $\mathrm{n}=1,968,30$ late ARM cases & $\begin{array}{l}\text { Cross- } \\
\text { sectional }\end{array}$ & Seafood & $0.68(0.2-2.5)$ \\
\hline $\begin{array}{l}\text { NHANES } \\
\text { [Heuberger et al., 2001] }\end{array}$ & USA & $\begin{array}{l}\mathrm{n}=7,405 ; 644 \text { cases of early } \\
\text { ARM, } 53 \text { cases of late ARM }\end{array}$ & $\begin{array}{l}\text { Cross- } \\
\text { sectional }\end{array}$ & $\begin{array}{l}\text { Fish } \geq 5 \\
\text { servings/month }\end{array}$ & $\begin{array}{l}1.0(0.7-1.4) \\
\text { early ARM } \\
0.4(0.2-1.2) \\
\text { late ARM }\end{array}$ \\
\hline $\begin{array}{l}\text { POLA } \\
\text { [Delcourt et al., 2007] }\end{array}$ & France & $\mathrm{n}=701 ; 48$ ARM cases & $\begin{array}{l}\text { Cross- } \\
\text { sectional }\end{array}$ & $\begin{array}{l}\text { Fatty fish } \geq 1 \\
\text { serving/month } \\
\text { White fish }\end{array}$ & $\begin{array}{l}0.42(0.21-0.83) \\
1.41(0.65-3.04)\end{array}$ \\
\hline $\begin{array}{l}\text { EUREYE } \\
\text { [Augood et al., 2008] }\end{array}$ & Europe & $\begin{array}{l}105 \text { cases of NV-ARM, 2,170 } \\
\text { controls }\end{array}$ & $\begin{array}{l}\text { Cross- } \\
\text { sectional }\end{array}$ & $\begin{array}{l}\text { Fatty fish } \geq 1 \\
\text { serving/week } \\
\text { DHA } \\
\text { EPA }\end{array}$ & $\begin{array}{l}0.47(0.33-0.68) \\
0.32(0.12-0.87) \\
0.29(0.11-0.73)\end{array}$ \\
\hline $\begin{array}{l}\text { Nurses and Health } \\
\text { Professionals Studies } \\
\text { [Cho et al., 2001] }\end{array}$ & USA & $\begin{array}{l}\mathrm{n}=72,489 ; 567 \text { incident } \\
\text { cases of ARM with visual loss }\end{array}$ & $\begin{array}{l}\text { Prospective } \\
\text { (10 years) }\end{array}$ & $\begin{array}{l}\text { Fish } \geq 4 \\
\text { servings/week } \\
\text { DHA }\end{array}$ & $\begin{array}{l}0.65(0.46-0.91) \\
0.70(0.52-0.93)\end{array}$ \\
\hline $\begin{array}{l}\text { Blue Mountains } \\
\text { Eye Study } \\
\text { [Chua et al., 2006] }\end{array}$ & Australia & $\begin{array}{l}\mathrm{n}=2,258 ; 158 \text { and } 26 \\
\text { incident early and late cases }\end{array}$ & $\begin{array}{l}\text { Prospective } \\
\text { (5 years) }\end{array}$ & $\begin{array}{l}\mathrm{n}-3 \\
\text { Fish } \geq 1 \\
\text { serving/week } \\
\text { Fish } \geq 3 \\
\text { servings/week }\end{array}$ & $\begin{array}{l}0.41(0.22-0.75) \\
\text { early } \\
0.58(0.37-0.90) \\
\text { early } \\
0.25(0.06-1.00) \\
\text { late }\end{array}$ \\
\hline $\begin{array}{l}\text { Reykjavik Study } \\
\text { [Arnarsson et al., 2006] }\end{array}$ & Iceland & $\begin{array}{l}\mathrm{n}=846 ; 126 \text { incident cases } \\
\text { of early ARM }\end{array}$ & $\begin{array}{l}\text { Prospective } \\
\text { (5 years) }\end{array}$ & $\begin{array}{l}\text { Herring } \geq 2 \\
\text { servings/week }\end{array}$ & $0.61(0.37-1.00)$ \\
\hline $\begin{array}{l}\text { Clinical study } \\
\text { [Seddon et al., 2003b] }\end{array}$ & USA & $\begin{array}{l}\mathrm{n}=261 \text { early ARM cases, } 101 \\
\text { progressions to late ARM }\end{array}$ & $\begin{array}{l}\text { Prospective } \\
\text { ( } 4.6 \text { years) }\end{array}$ & $\begin{array}{l}\text { Fish } \geq 2 \\
\text { servings/week }\end{array}$ & $0.88(0.49-1.60)$ \\
\hline $\begin{array}{l}\text { AREDS } \\
\text { [SanGiovanni et al., 2008] }\end{array}$ & USA & $\begin{array}{l}\mathrm{n}=2,132 \text { early ARM cases, } \\
113 \text { incident CGA, } \\
198 \text { incident NV-ARM }\end{array}$ & $\begin{array}{l}\text { Prospective } \\
\text { (6 years) }\end{array}$ & $\begin{array}{l}\mathrm{EPA}+\mathrm{DHA} \\
\text { Tuna }=1-2 \\
\text { servings/week }\end{array}$ & $\begin{array}{l}\text { CGA: } 0.45(0.23-0.90) \\
\text { NV-ARM: } 0.85(0.47-1.54) \\
\text { CGA: } 0.57(0.27-1.19) \\
\text { NV-ARM: } 0.48(0.24-0.95)\end{array}$ \\
\hline
\end{tabular}

CGA = Central geographic atrophy; NV-ARM = neovascular ARM; AREDS = Age-related Eye Disease Study; POLA = Pathologies Oculaires Liées à l’Age; NHANES = National Health and Nutrition Examination Survey. 
a series of clinical studies examining the relationship between n-3 PUFA intake and AD risk and symptoms. In addition, Cole and Frautschy [2006] claim that DHA protects from amyloid and dendritic pathology in an $\mathrm{AD}$ mouse model.

\section{Epidemiological Studies}

We found 11 prospective, 3 cross-sectional and 1 casecontrol study examining n-3 PUFA status (dietary intake or blood levels) and risk of developing AD. These studies are summarised in table 4 . Overall, 1 study shows a positive relationship between plasma phospholipid levels and risk of $\mathrm{AD}$, while 2 studies demonstrate no significant effect and 12 studies report an inverse relationship between AD risk and n-3 PUFA status.

\section{Randomised Clinical Trials}

There are 3 reported RCTs of $n-3$ PUFA supplementation in patients diagnosed as probably having $\mathrm{AD}$ (table 5). The study of longest duration (6 months) administered a combination of DHA and EPA and found improvements in cognitive decline in a subgroup of patients with mild AD. In another small study, patients with mild cognitive impairment also had improved memory, while a study using EPA found no benefits.

In summary, cell culture animal models show promising mechanistic support for DHA in AD. Non-randomized epidemiological studies examining n-3 PUFA intake or blood levels support a role of DHA in the prevention of AD. Data from clinical trials are limited but suggestive that DHA may be of benefit to patients with milder forms of AD. Larger, randomised clinical trials in the prevention and treatment of $\mathrm{AD}$ are needed before conclusions can be drawn.

\section{Schizophrenia}

For a number of years, there have been studies on $n-3$ PUFA and schizophrenia, starting with those which reported reduced levels of PUFA, particularly AA and DHA, in the cell membranes of red blood cells from schizophrenic patients [for review, see Peet, 2008]. This has led to double-blind placebo-controlled trials that $n-3$ fatty acids might prevent conversion from a prodromal state into first episode psychosis, and reduce the antipsychotic drug requirement in first episode patients. Results from 5 clinical trials have produced inconsistent results with small effect sizes, which may be of little clinical significance [Ross et al., 2007]. Peet [2008] discusses the problems associated with single nutrient studies and suggests that optimal nutritional treatment will most likely involve combinations of nutrients.

In summary, results from 5 clinical trials have produced inconsistent results with small effect sizes, which may be of little clinical significance.

\section{Huntington's Disease}

Huntington's disease is a very severe disease of the brain, usually beginning around the age of 30 years. Significant features of the disease include selective neuronal loss in the striatum and mitochondrial dysfunction. Studies from animal models of Huntington's disease show significant benefits from treatment with E-EPA [Murck and Manku, 2007]. An open label study in humans reported a beneficial effect of E-EPA on motor function [Vaddadi et al., 2002] and this was confirmed by a small placebo-controlled trial in late-stage Huntington's disease [Puri et al., 2002]. A recent double-blind randomised, placebo-controlled study with E-EPA showed no benefit, but there were some promising data from a subgroup, suggesting that further studies are warranted [Puri et al., 2005].

In summary, results from animal studies and several small-scale human studies report some beneficial effects in some of the studies with pure E-EPA, though clearly further studies are warranted. Furthermore, the design and appraisal of studies in this entire field need to be more critically evaluated.

\section{A Root of Brain Disorders in Food}

Low birthweight is the strongest predictor of risk for chronic ill health, heart disease, stroke and diabetes along with learning and numeracy difficulties, behavioural pathology, low skill level, restricted job opportunities and crime.

As birthweight falls, the incidence of severe neurodevelopmental disorders rises sharply from about 1 in 1,000 live births to over 200 in 1,000 live births below $1.5 \mathrm{~kg}$ (UK Office of Population Censuses and Surveys data). These will be mostly premature deliveries. The consequences in terms of disability impose a disproportionately high cost on the health services and society because of the life-long impact. With courts in the UK awarding in some cases over GBP 4 million for alleged mishap, the cost of severe central nervous system damage associated 
Table 4. AD: epidemiological studies and n-3 PUFA

\begin{tabular}{|c|c|c|c|c|}
\hline Type of study & $\begin{array}{l}\text { Age/length } \\
\text { of follow-up } \\
\text { years }\end{array}$ & Outcome & $\begin{array}{l}\text { Relationship } \\
\text { (relative } \\
\text { to AD risk) }\end{array}$ & Ref. \\
\hline $\begin{array}{l}\text { Prospective cohort } \\
\text { (Rotterdam Study) }\end{array}$ & $55+/ 2.1$ & Higher fish consumption is associated with lower AD risk & Inverse & $\begin{array}{l}\text { Kalmijn } \\
\text { et al., } 1997\end{array}$ \\
\hline $\begin{array}{l}\text { Prospective cohort } \\
\text { (Rotterdam Study) }\end{array}$ & $55+/ 6$ & No association between n-3 PUFA and AD & None & $\begin{array}{l}\text { Engelhart } \\
\text { et al., } 2002\end{array}$ \\
\hline $\begin{array}{l}\text { Prospective cohort } \\
\text { (PAQUID Study) }\end{array}$ & $68+/ 2-7$ & Fish or seafood once a week lowered risk of $\mathrm{AD}$ & Inverse & $\begin{array}{l}\text { Barberger- } \\
\text { Gateau } \\
\text { et al., } 2002\end{array}$ \\
\hline $\begin{array}{l}\text { Prospective cohort } \\
\text { (Chicago Health } \\
\text { and Aging Project) }\end{array}$ & $65+/ 3.9$ & $\begin{array}{l}\text { Fish once a week or more lowered risk of } \mathrm{AD} \text { by } 60 \% \text {; DHA and } \mathrm{n}-3 \\
\text { PUFA were associated with lower AD risk; EPA was not associated } \\
\text { with AD }\end{array}$ & Inverse & $\begin{array}{l}\text { Morris } \\
\text { et al., } 2003\end{array}$ \\
\hline $\begin{array}{l}\text { Prospective cohort } \\
\text { (Canadian Study of } \\
\text { Health and Aging) }\end{array}$ & $65+/ 5$ & $\begin{array}{l}\text { Increased EPA in plasma PL of cognitively impaired cases; increased } \\
n-3 \text { PUFA and PUFA in dementia cases }\end{array}$ & Direct & $\begin{array}{l}\text { Morris } \\
\text { et al., } 2003\end{array}$ \\
\hline $\begin{array}{l}\text { Cross-sectional } \\
\text { (Canadian Study of } \\
\text { Health and Aging) }\end{array}$ & $65+/$ n.a. & $\begin{array}{l}\text { No difference in EPA, DHA, PUFA, n-3 and n- } 6 \text { PUFA concentra- } \\
\text { tions in plasma PL between controls and dementia or cognitively } \\
\text { impaired cases }\end{array}$ & None & $\begin{array}{l}\text { Morris } \\
\text { et al., } 2003\end{array}$ \\
\hline $\begin{array}{l}\text { Prospective (Cardio- } \\
\text { vascular Health } \\
\text { Cognition Study) }\end{array}$ & $65+/ 5.4$ & $\begin{array}{l}\text { Fatty fish at least twice a week is associated with risk of AD reduced } \\
\text { by } 41 \% \text {; no effect for people with the APOE } \varepsilon 4 \text { allele }\end{array}$ & Inverse & $\begin{array}{l}\text { Huang } \\
\text { et al., } 2005\end{array}$ \\
\hline $\begin{array}{l}\text { Prospective cohort } \\
\text { (Framingham } \\
\text { Heart Study) }\end{array}$ & $76 / 9.1$ & $\begin{array}{l}\text { Increased PC DHA levels in plasma ( } 18 \mathrm{~g} / \text { day of DHA or } 3 \text { servings/ } \\
\text { week of fish) associated with lower dementia risk }\end{array}$ & Inverse & $\begin{array}{l}\text { Schaefer } \\
\text { et al., } 2006\end{array}$ \\
\hline Cross-sectional & n.a. & $\begin{array}{l}\text { Lower fish and } n-3 \text { PUFA intake for AD female patients; } \\
\text { increased } n-6 / n-3 \text { ratio for male and female AD patients }\end{array}$ & Inverse & $\begin{array}{l}\text { Otsuka } \\
\text { et al., } 2002\end{array}$ \\
\hline $\begin{array}{l}\text { Case-control } \\
\text { study }\end{array}$ & 76.5/n.a. & Lower serum cholesteryl ester EPA and DHA in $\mathrm{AD}$ patients & Inverse & $\begin{array}{l}\text { Tully } \\
\text { et al., } 2003\end{array}$ \\
\hline Cross-sectional & 82.7/n.a. & $\begin{array}{l}\text { Lower } 20: 5 n-3 \text {, DHA and total n-3 PUFA in plasma PL, PC and PE } \\
\text { for AD patients; increased total n-6 PUFA in plasma total PL for AD } \\
\text { patients; no difference in fatty acid levels of lysoPC }\end{array}$ & Inverse & $\begin{array}{l}\text { Conquer } \\
\text { et al., } 2000\end{array}$ \\
\hline $\begin{array}{l}\text { Prospective cohort } \\
\text { (Zutphen Elderly } \\
\text { Study) }\end{array}$ & $70+/ 5$ & $\begin{array}{l}\text { Lower 5-year cognitive decline among fish consumers; increased } \\
\text { EPA + DHA intake is associated with reduced 5-year } \\
\text { cognitive decline }\end{array}$ & Inverse & $\begin{array}{l}\text { van Gelder } \\
\text { et al., } 2007\end{array}$ \\
\hline $\begin{array}{l}\text { Prospective cohort } \\
\text { (Atherosclerosis Risk } \\
\text { in Communities) }\end{array}$ & $50+/ 10$ & $\begin{array}{l}\text { Increased AA and reduced } 18: 2 n-6 \text { in plasma cholesteryl esters are } \\
\text { associated with higher risk of cognitive decline; increased plasma } \\
\text { EPA + DHA is associated with a lower risk of word fluency decline }\end{array}$ & Inverse & $\begin{array}{l}\text { Beydoun } \\
\text { et al., } 2007\end{array}$ \\
\hline $\begin{array}{l}\text { Prospective cohort } \\
\text { (Three City Study) }\end{array}$ & $65+/ 4$ & $\begin{array}{l}\text { Higher baseline plasma EPA or DHA is associated with a lower risk } \\
\text { of dementia }\end{array}$ & Inverse & $\begin{array}{l}\text { Samieri } \\
\text { et al., } 2008\end{array}$ \\
\hline Prospective cohort & $64+/ 4$ & $\begin{array}{l}\text { Higher erythrocyte DHA is associated with better cognition; after } \\
\text { controlling for APOE } \varepsilon 4 \text { allele, only total erythrocyte n-3 PUFA was } \\
\text { associated with cognition }\end{array}$ & Inverse & $\begin{array}{l}\text { Whalley } \\
\text { et al., } 2008\end{array}$ \\
\hline
\end{tabular}

Updated from Boudrault et al. [2009], with permission. PC = phosphatidylcholine; $\mathrm{PE}=$ phosphatidylethanolamine; $\mathrm{PL}=$ total phospholipids; n.a. = not applicable. 
Table 5. AD: clinical trials and n-3 PUFA

\begin{tabular}{|c|c|c|c|c|}
\hline Type of Trial & Population & Treatment & Outcome & Ref. \\
\hline $\begin{array}{l}\text { Randomised, double- } \\
\text { blind and placebo- } \\
\text { controlled (OmegAD) }\end{array}$ & $\begin{array}{l}\text { AD patients } \\
(\mathrm{n}=204 ; \\
\text { age }=74 \text { years })\end{array}$ & $\begin{array}{l}1.7 \mathrm{~g} \mathrm{DHA}+0.6 \mathrm{~g} \mathrm{EPA} \\
\text { per day for } 6 \text { months }\end{array}$ & $\begin{array}{l}\text { No effect on cognitive decline; reduced } \\
\text { cognitive decline only for subgroup of } \\
\text { patients with mild AD }\end{array}$ & $\begin{array}{l}\text { Freund-Levi } \\
\text { et al., } 2006\end{array}$ \\
\hline Pilot study & $\begin{array}{l}\text { AD patients } \\
(n=20 ; \\
\text { age }=65+\text { years })\end{array}$ & $\begin{array}{l}500 \mathrm{mg} \text { E-EPA twice } \\
\text { a day for } 12 \text { weeks }\end{array}$ & $\begin{array}{l}\text { No effect on cognitive decline; increased } \\
\text { EPA, DPAn-3 and total n-3 in erythrocyte } \\
\text { membrane }\end{array}$ & $\begin{array}{l}\text { Boston } \\
\text { et al., } 2004\end{array}$ \\
\hline $\begin{array}{l}\text { Randomised, double- } \\
\text { blind and placebo- } \\
\text { controlled }\end{array}$ & $\begin{array}{l}\mathrm{AD} \text { and } \mathrm{MCI} \\
\text { patients }(\mathrm{n}=8 \\
\text { age }=67 \text { years })\end{array}$ & $\begin{array}{l}240 \mathrm{mg} \text { AA and } 240 \mathrm{mg} \\
\text { DHA per day for } 90 \text { days }\end{array}$ & $\begin{array}{l}\text { No effect on memory and attention for AD } \\
\text { patients; improved immediate memory and } \\
\text { attention for MCI patients }\end{array}$ & $\begin{array}{l}\text { Kotani } \\
\text { et al., } 2006\end{array}$ \\
\hline
\end{tabular}

Adapted from Boudrault et al. [2009], with permission. MCI = Mild cognitive impairment; DPAn-3 = docosapentaenoic acid.

with pregnancy and the perinatal condition is in the order of GBP $4-8$ billion a year.

Studies in London's Eastend, and those of others, describe this issue as a major cause of health inequalities and hence social inequalities and behavioural disorders. They link poor maternal/foetal nutrition and living conditions causatively to low birthweight regardless of socioeconomic status, ethnicity or smoking habit [Doyle et al., 1989; Wynn et al., 1994; Rees et al., 2005].

Whilst by no means offering an explanation for all mental ill health, the logic and evidence base of poor maternal nutrition affecting brain development is compelling. This is especially true in the current environment in which the collapse of fisheries this and last century has been linked to a decline in mental health. The rise in $n-6$ fatty acids from the escalation of $n-6$ rich vegetable oils in food processing and the kitchen is also considered to contribute [Hibbeln et al., 2004, 2006b].

Similarly, the increasing practice of intensive poultry and beef production has debased these traditionally n-3-rich food sources. Studies in chicken meat in 1970 gave a figure of $170 \mathrm{mg} / 100 \mathrm{~g}$ meat. In 2004, the level was down to $25 \mathrm{mg} / 100 \mathrm{~g}$. Organic chicken studied were little different as they were fed on organic cereal which still had little $\mathrm{n}-3$. This loss is a consequence of lack of exercise and foraging for food, gene selection for rapid weight gain and cereal feeding. The birds are also often kept in buildings where the artificial lights stay on for $22 \mathrm{~h} /$ day to encourage feeding. Moreover, both chicken and beef now produce 3-5 times the dietary energy compared to protein - which is obesigenic and atherogenic - and the opposite of how it should be.

Fat Intake and CNS Functioning:

Ageing and Disease
Rising obesity is of major concern, and how much is due to lifestyle, genetics, food composition and even deficits of brain regulatory systems [Stice et al., 2008] is an open question. However, it is an inescapable fact that eating more calories than is needed results in weight gain, even if there is genetic variation between one person and the next. The rise in hidden calories in food which is associated with the proportionate decrease, or even a loss, of nutrients is a matter ignored in the equation and it requires urgent investigation. This is especially so as obesity leads to type II diabetes which raises the risk of neurodegenerative disorders later in life [de Sá Roriz-Filho et al., 2008; Cukierman-Yaffee, 2009].

\section{Implications of the Food System for Brain Disorders in Developing Countries}

There is an urgent need to address the security of the food system. In intensive systems, the delivery of a diet balanced in EFA has been distorted, which is exacerbating the reduction of long-chain $\mathrm{n}-3$ fatty acids from sea foods and indeed, from the few land foods traditionally rich in n-3 fatty acids, such as those derived from the green foods naturally eaten and seldom provided in intensive systems. Moreover, modern foods rich in fat and salt are being exported from Europe and the USA to developing countries (fig. 4) with a predictable rise in obesity, diabetes, cardiovascular disease and mental ill health. With the knowledge available to the World Health Organization and Food and Agriculture Organization, this is an unethical and unacceptable situation.

Ann Nutr Metab 2009;55:202-228 
Fig. 4. A supermarket in Beijing selling high fat, high saturated fat animal products derived from a subsidised system that undercuts traditional farm products in China. The recommendation is that a new food security enquiry should be called to investigate the situation and provide a green paper for international consultation on the way forward. It should include the expansion of fresh water and marine systems in both cold and warm habitats, and outline the effects of plant and animal selection as well as of feeding on the nutritional value pertaining to the health of brain development and sustenance.

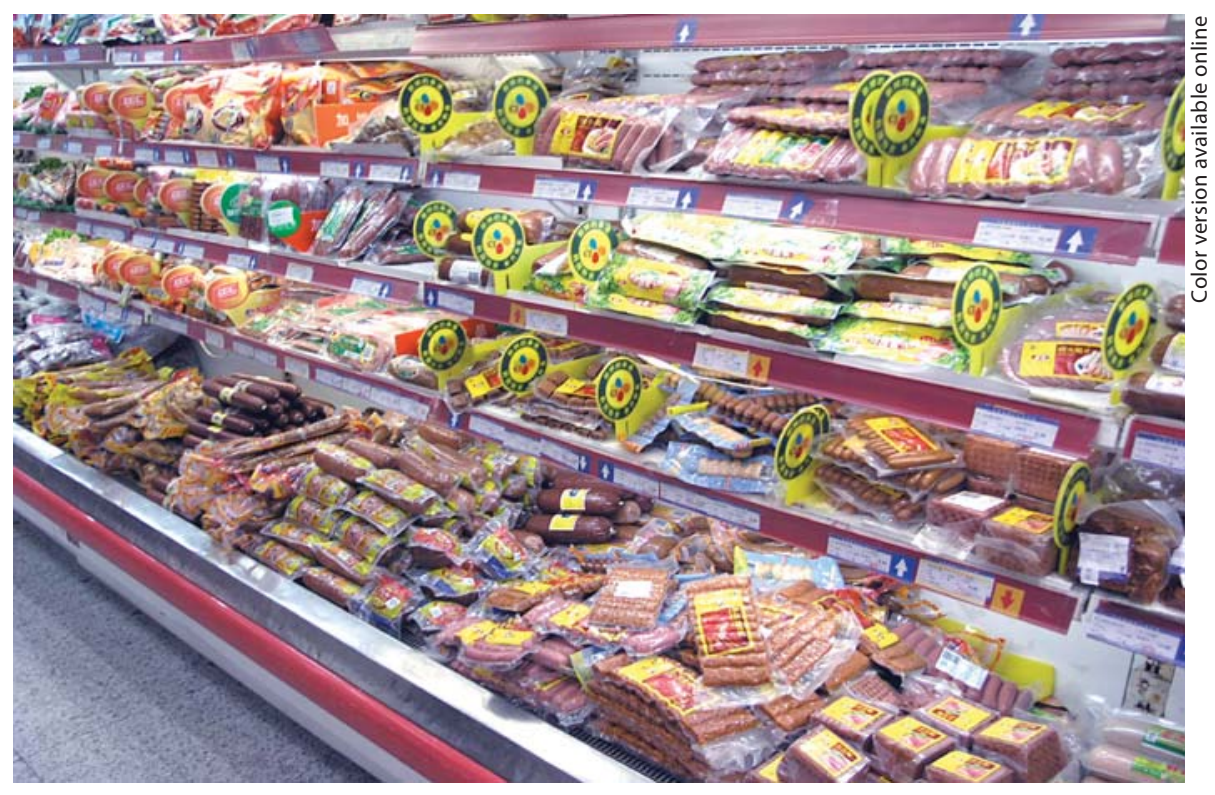

Figure 4 shows an example of the present export to developing countries of high fat, high salt products. Previously in 1990, the Straits Times in Kuala Lumpur reported several medical authorities concerned about this issue and the rise in obesity and diabetes in Kuala Lumpur. A similar situation was witnessed by one of us (M.A.C.) in the Philippines. Heart disease had become the number 1 killer in Manila. At the same time in Indonesia, the Ministry of Health was dealing with 2 different faces of malnutrition - micronutrient and iodine deficiencies in the country, and heart disease, diabetes and obesity in the cities. Mental ill health follows, as predicted by the Global Forum for Health.

\section{Summary and Recommendations}

\section{Assumptions and Limitations}

(1) Brain disorders and mental ill health. The cost of brain disorders and mental ill health has been rising sharply. It has overtaken all other burdens of ill health. In 2004, it cost EUR 386 billion (2004 prices) to the 25 states that were members of the European Union at that time. In the UK in 2007, the cost was GBP 77 billion, greater than those for heart disease and cancer combined. The global cost is estimated to rise to be in the top 3 burdens of ill health worldwide by 2020 (Global Forum for Health).
(2) DHA has, despite similar molecules of only 1 double bond difference such as docosapentaenoic acid, been the only n-3 fatty acid used as a major structural and functional constituent of the photoreceptor, neurons and their signalling synapses throughout the 600 million years of animal evolution. This is one of many compelling reasons for the absolute necessity of DHA for the human brain.

(3) The question arises as to how the requirement for DHA in the brain can be met. DHA can be synthesised from ALA; however, this process appears to be very inefficient. Data in primate and rodent/animal experiments demonstrate dietary DHA is used for brain growth with an efficiency that is an order of magnitude greater compared with its endogenous synthesis from ALA, which is likely to provide an advantage during growth and maintenance.

(4) We argue that the priority in the biological development of humans is the brain. Based on this fact, one can argue that the target balance of $n-6$ to $n-3$ PUFAs in the diet should be between 2:1 and 1:1.

(5) The neural system develops extensively prenatally and in the first years of life, and is influenced by multigenerational considerations. There is convincing evidence that early, neural developmental milestones determine long-term brain functional capacity. Once brain milestones are passed, it may be too late to intervene with long-chain PUFA in neurological/neuropsychological disorders such as depression and bipolar disorder, mood and cognition, AD, AMD, schizophrenia and Huntington's disease. However, this does not mean they may not 
help stabilise or even partially reverse such conditions. There is a need for well-designed trials with sufficient power, adequate length and supplements that are relevant to supporting the neurovascular systems. Factors that might influence the delivery of energy to brain cells need to be researched in view of their extraordinarily high requirement and dependence. In addition, we acknowledge a potential role for EPA in these conditions due to its influence on improving vascular function and the resulting effect on the delivery of glucose to the brain.

(6) We consider that the ability to conduct RCTs on the role of AA and DHA in brain development in humans in the perinatal period is likely to be limited by ethical considerations. In adult brain disorders, any RCT will face the difficulty of addressing a system in which the origin of the disorder is likely to have a life history, possibly including the developmental period.

(7) In view of the rising burden of brain disorders, there is an urgent need to target food production to be in line with requirements for the brain, vascular and general health. The future requirements for the increasing human population cannot be met by the diminishing fishery catch. Furthermore, this requirement is unlikely to be met by land products. Additionally, land-based products do not have the full package of essential nutrients found in seafood (iodine, n-3 fatty acids, $\mathrm{Se}, \mathrm{Cu}$, etc). We recommend expansion of both fresh water and marine aquaculture with an extension to the use of extensive, agricultural principles to expand the productivity of the estuaries, coast lines and oceans. Apart from producing food for an expanding population, such a policy would help address global warming through the enhancement of carbon dioxide fixation.

(8) In developing countries where children may be in energy deficit and it is planned to increase energy density of the diet with fats and oils, every encouragement should be given to the development of indigenous oils that have a more physiological balance of linoleic acid and ALA as opposed to importing the linoleic acid-rich oils which dominate the Western markets. Similarly, developing countries need to guard against importing food products that are high in fats that are rich in atherogenic and thrombogenic fats and do not provide a balance of EFAs.

(9) Limitations of current studies on brain research in humans:

- studies thus far have been carried out over too short time scales and with too small numbers of subjects;

- epidemiological evidence on benefits attributed to n-3 fatty acids is associated with fish and seafood and not just fish fat;

Fat Intake and CNS Functioning:

Ageing and Disease
- seafood and fish are not just oils, they are particularly rich in iodine, $\mathrm{Se}, \mathrm{Cu}, \mathrm{Zn}$ and $\mathrm{Mn}$ as well as a variety of antioxidants and fat soluble vitamins;

- there is evidence that single nutrients do not have the same effect as the integrated food or even nutrient cluster; interaction between the different macro- and micronutrients should be recognised and encouraged as a specific direction in research.

\section{Summary of Requirements}

\section{Daily Requirement of Adult Brain for PUFA}

Limited data from 1 human study reveal that there is a requirement (based on turnover of labelled fatty acids) of approximately $18 \mathrm{mg}$ of AA per adult brain/day and $5 \mathrm{mg}$ DHA/brain/day as free fatty acid in the plasma compartment. More research is required to translate this figure into a daily dietary intake of AA and DHA, particularly as both AA and DHA are compartmentalised into different phosphoglycerides, triglycerides and cholesterol ester molecules and avidly taken up by cell membrane phosphoglycerides in all organs.

No studies have been conducted on other plasma lipids or red blood cells, which are potentially rich sources of long-chain PUFA for the brain as phospholipids. There is some evidence (in rats) that plasma lysoPC-DHA could be a carrier of DHA to brain. The concentrations of AA and DHA are high in the vascular endothelium and the brain, but the proportions in the free fatty acid fractions are very low, suggesting that mechanisms other than free fatty acids may be responsible for the biomagnifications. As with the placenta, it is plausible that phospholipids are used with selective sn-2 incorporation accounting for the biomagnifications across the cell membranes. More basic research is required on the turnover from sources other than the free fatty acid fraction in plasma.

\section{Long-Chain n-3 PUFA and Depression and Bipolar Disorder}

Encouraging data have been obtained from some epidemiological and intervention studies in this area. Doses used in intervention studies have ranged from 0.6 to 6 g/day. Future directions in this area should involve studies with purified preparations of long-chain $n-3$ PUFA (alone and in combination), attention to mode of delivery, dose-response studies and studies on the duration required for greatest benefit, and they should be adequately powered for the purpose. Studies are needed to delineate the importance of n-3 PUFA as monotherapy 
Table 6. Current level of evidence for long-chain $n-3$ fatty acids in relation to CNS functioning

\begin{tabular}{|c|c|}
\hline Condition & Evidence strength \\
\hline Depression & probable \\
\hline Bipolar disorder & possible \\
\hline Cognitive decline & possible \\
\hline \multicolumn{2}{|l|}{ Aggression, hostility and } \\
\hline anti-social behaviour & possible \\
\hline Age-related macular degeneration & possible \\
\hline Alzheimer's disease & insufficient evidence to date \\
\hline Schizophrenia & insufficient evidence to date \\
\hline Huntington's disease & insufficient evidence to date \\
\hline
\end{tabular}

or adjunct therapy, with identification of the mechanism(s) of action of these PUFA in depression and bipolar disorder. The evidence suggests that there are more consistent benefits with the use of EPA and/or fish oil at a level of 1-2 g/day. The strength of the evidence is regarded as 'probable' for depression.

In the case of bipolar disorder, where there have been fewer studies, the strength of the evidence is 'possible'.

\section{Cognitive Decline}

There is limited evidence in adults to support the relationship between long-chain n-3 PUFA intake/status and altered cognition, although there is support from observational studies. Future directions should involve thorough intervention studies in appropriate subjects using sufficiently sensitive tests designed to measure effects in mood and cognition.

The strength of the evidence is regarded as 'possible'.

\section{Aggression, Hostility and Anti-Social Behaviour}

Epidemiological studies have suggested a link between poor EFA status and violence. The results of intervention studies with long-chain n-3 PUFA plus other ingredients have been equivocal. The study populations have been heterogeneous, sometimes with only a small number of subjects. Despite this, there are some encouraging data emerging. Studies in prisoners in the USA have provided some support regarding micronutrients.

A recent RCT in the UK brought about a $\geq 30 \%$ reduction in violence amongst violent young offenders in prison. A 24-hour video surveillance, as employed for legal purposes in the prisons, was used as the outcome measure. The intervention was a combination of EFAs and micronutrients on the grounds of their interdependence. The study is being replicated on a larger scale. This is clearly an area where more research is required in defined populations with larger numbers of subjects.

The strength of the evidence is regarded as 'possible'.

\section{Age-Related Maculopathy}

Epidemiological and observational data are strongly suggestive of a $30-40 \%$ reduction of risk for ARM in regular fish eaters. On this basis, several interventional studies are currently ongoing, examining the potential benefit of supplementation with long-chain $n-3$ PUFA for the prevention of late ARM, but none have been published to date. There is also a lack of observational data with blood measurement of fatty acids, which could confirm the dietary data.

The strength of the evidence is regarded as 'possible'.

\section{Alzheimer's Disease}

Epidemiological studies examining long-chain n-3 PUFA intake or blood levels support a role of DHA in the prevention of AD. Cell culture and animal models show promising mechanistic support for DHA in AD. Data from clinical trials are limited, but show some evidence that DHA may be of benefit to patients with milder forms of AD. Larger, randomised clinical trials in the prevention and treatment of $\mathrm{AD}$ are required.

The strength of the evidence is regarded as 'insufficient evidence to date'.

\section{Schizophrenia}

Results from 5 clinical trials have produced inconsistent results with small effect sizes, which may be of little clinical significance.

The strength of the evidence is regarded as 'insufficient evidence to date'.

\section{Huntington's Disease}

Results from animal studies and several small-scale human studies report some beneficial effects in some of the studies with pure E-EPA.

The strength of the evidence is regarded as insufficient evidence to date'.

\section{Recommendations for Adults: CNS Function (table 6)}

\section{Probable}

- Supplementation with long-chain n-3 PUFA as treatment for depression. Dose, treatment time, preferred n-3 PUFA (EPA, DHA or both), adjunct or monotherapy yet to be defined. 
Possible

- Supplementation with long-chain n-3 PUFA as treatment for bipolar disorder. Dose, treatment time, preferred n-3 PUFA, adjunct or monotherapy yet to be defined.

- Supplementation with long-chain n-3 PUFA in aggression, hostility and antisocial behaviour. Dose, preferred n-3 PUFA, adjunct or monotherapy yet to be defined.

- Supplementation with long-chain n-3 PUFA in agerelated macular degeneration. Dose and preferred n-3 PUFA yet to be defined.

- Supplementation with long-chain n-3 PUFA in improvements in cognitive decline. Dose and preferred n-3 PUFA yet to be defined.

\section{Insufficient Evidence to Date}

- Supplementation with long-chain n-3 PUFA as treatment for AD.

- Supplementation with long-chain n-3 PUFA as treatment for Schizophrenia.

- Supplementation with long-chain n-3 PUFA as treatment for Huntington's disease.

- Requirement for optimal neurogenesis and relevance of early development to subsequent risk to dementia and $\mathrm{AD}$.

\section{Concluding Remarks}

(1) There can be little doubt about the essentiality of DHA and AA for the brain. The rise in brain disorders is the most disturbing feature of the changing panorama of disease and disorder. There is a need to address the potential role of the food system as the root cause of globalisation of mental ill health. Based on the epidemiology and supported by basic science, there is a need to enhance better use of fresh water and marine food webs, including attention to the ways and means of restoring healthy rivers, estuaries, coastlines and all aspects of marine productivity. At the same time, the distortions of food and animal production which have amplified the non-essential, atherogenic and obesigenic fats at the expense of the fats essential to vascular, immune system and brain development, would need to be corrected. The Food and Agriculture Organization/World Health Organization report on dietary fats and oils in 1978 specifically commented on this need, but the situation has become more exaggerated since then.

(2) The Japanese have the least depression, cardiovascular disease, and breast and colon cancer of the indus- trialised nations. Any assessment for optimal intakes and balance of fatty acids required should take advantage of the amounts eaten in the traditional Japanese diets. However, the presence of competing fatty acids and the requirement for adequate antioxidants in the diet need to be taken into account.

(3) The recommendations outlined here emphasise the need for more research:

- to define the requirement of the adult brain for a continuing supply of AA and DHA from the plasma, for optimal neural functioning;

- to define the requirement in adults and children for the optimal development of the neurovascular system in the next generation, with the inclusion of epigenetic studies;

- on the role of PUFA in a variety of neural disorders including depressive illness, age-related macular degeneration, aggression, hostility and anti-social behaviour, AD, schizophrenia and Huntington's disease;

- on AA and its companion long-chain PUFAs;

- on a cost-benefit analysis to assess the potential contribution of an optimal intake of AA and DHA on health status and healthcare costs.

\section{Acknowledgments}

The assistance of Dr. Elizabeth Manickam (Deakin University, Australia), Ms. Catherine Lehane (IBCHN, London Metropolitan University, UK), Dr. Cecile Delcourt (INSERM, Bordeaux, France), Dr. V. Flood and Prof. P. Mitchell (University of Sydney, Australia), and Prof. Kebreab Ghebremeskel (London Metropolitan University, UK) is gratefully acknowledged. Excerpts within this report are reproduced with permission from Thomson Reuters (Scientific) Ltd. and Stahl LA, Begg DP, Weisinger RS, Sinclair AJ [The role of omega-3 fatty acids in mood disorders. Curr Opin Invest Drugs 2008;9:57-64. Copyright (C) 2008 Thomson Reuters (Scientific) Ltd.], and with permission from Elsevier Inc. in relation to tables 4 and 5 from Boudrault et al. [2009].

\section{Disclosure Statement}

Prof. Michael Crawford has no conflicts of interest at this time or during the proceedings or after. Michael Crawford is a trustee of the Mother and Child Foundation and Vice President of the Brain Trust (see PS) and Chairman of the McCarrison Society, none of which have any vested interests. Prof. Richard Bazinet has no conflicts of interest. Prof. Andrew Sinclair has no conflicts of interest. He has received research funds from Meat \& Livestock, Australia, and is a scientific advisor to The Omega 3 Centre (Australia). 


\section{References}

Abeywardena MY, Head RJ: Long chain n-3 polyunsaturated fatty acids and blood vessel function. Cardiovasc Res 2001;52:361-371.

- Akbar M, Calderon F, Wen Z, Kim HY: Docosahexaenoic acid: a positive modulator of Akt signaling in neuronal survival. Proc Natl Acad Sci USA 2005;102:10858-10863.

-Andlin-Sobocki P, Jönsson B, Wittchen HU, Olesen J: Cost of disorders of the brain in Europe. Eur J Neurol 2005;12(suppl 1):1-27.

-Appleton KM, Rogers PJ, Ness AR: Is there a role for n-3 long-chain polyunsaturated fatty acids in the regulation of mood and behaviour? A review of the evidence to date from epidemiological studies, clinical studies and intervention trials. Nutr Res Rev 2008;21:13-41.

-AgREDS Group: A randomized, placebo-controlled, clinical trial of high-dose supplementation with vitamins $\mathrm{C}$ and $\mathrm{E}$, beta carotene, and zinc for age-related macular degeneration and vision loss: AREDS report No. 8. Arch Ophthalmol 2001;119:1417-1436.

AREDS: Age-related Eye Disease Study 2 Manual of Procedures. 2006. www.areds2.org (accessed February 21, 2008).

-Arnarsson A, Sverrisson T, Stefansson E, Sigurdsson H, Sasaki H, Sasaki K, Jonasson F: Risk factors for five-year incident age-related macular degeneration: the Reykjavik Eye Study. Am J Ophthalmol 2006;142:419-428.

- Augood C, Chakravarthy U, Young I, et al: Oily fish consumption, dietary docosahexaenoic acid and eicosapentaenoic acid intakes, and associations with neovascular age-related macular degeneration. Am J Clin Nutr 2008; 88:398-406.

Barberger-Gateau P, Letenneur L, Deschamps V, Pérès K, Dartigues JF, Renaud S: Fish, meat, and risk of dementia: cohort study. BMJ 2002;325:932-933.

-Basselin M, Villacreses NE, Lee HJ, Bell JM, Rapoport SI: Chronic lithium administration attenuates up-regulated brain arachidonic acid metabolism in a rat model of neuroinflammation. J Neurochem 2007;102: 761-772.

Bazinet RP, Rao JS, Chang L, Rapoport SI, Lee HJ: Chronic carbamazepine decreases the incorporation rate and turnover of arachidonic acid but not docosahexaenoic acid in brain phospholipids of the unanesthetized rat: relevance to bipolar disorder. Biol Psychiatry 2006;59:401-407.

Beltz BS, Tlusty MF, Benton JL, Sandeman DC: Omega-3 fatty acids upregulate adult neurogenesis. Neurosci Lett 2007;415:154-158.

Benolken RM, Anderson RE, Maude MB: Lipid composition of Limulus photoreceptor membranes. Biochimica et biophysica acta 1975; 413:234-242.

Benolken RM, Anderson RE, Wheeler TG: Membrane fatty acids associated with the electrical response in visual excitation. Science 1973;182:1253-1254.
Beydoun MA, Kaufman JS, Satia JA, Rosamond W, Folsom AR: Plasma n-3 fatty acids and the risk of cognitive decline in older adults: the Atherosclerosis Risk in Communities Study. Am J Clin Nutr 2007;85:1103-1111.

- Birch EE, Garfield S, Hoffman DR, Uauy R, Birch DG: A randomized controlled trial of early dietary supply of long-chain polyunsaturated fatty acids and mental development in term infants. Dev Med Child Neurol 2000;42:174-181.

-Bitsanis D, Ghebremeskel K, Moodley T, Crawford MA, Djahanbakhch O: Gestational diabetes mellitus enhances arachidonic and docosahexaenoic acids in placental phospholipids. Lipids 2006;41:341-346.

Bloom M, Linseisen F, Lloyd-Smith J, Crawford MA: Insights from NMR on the Functional Role of Polyunsaturated Lipids in the Brain; in Maraviglia B (ed): 'Magnetic Resonance and Brain Function: Approaches from Physics' Proc 1998 Enrico Fermi Int School Physics, Enrico Fermi Lecture, Varenna,1999, pp 1-27.

Bosetti F, Weerasinghe GR, Rosenberger TA, Rapoport SI: Valproic acid down-regulates the conversion of arachidonic acid to eicosanoids via cyclooxygenase- 1 and -2 in rat brain. J Neurochem 2003;85:690-696.

Boston PF, Bennett A, Horrobin DF, Bennett CN: Ethyl-EPA in Alzheimer's disease: a pilot study. Prostaglandins Leukot Essent Fatty Acids 2004;71:341-346.

Boudrault C, Bazinet RP, Ma DW: Experimental models and mechanisms underlying the protective effects of $n-3$ polyunsaturated fatty acids in Alzheimer's disease. J Nutr Biochem 2009;20:1-10.

- Broadhurst CL, Wang Y, Crawford MA, Cunnane SC, Parkington JE, Schmidt WF: Brainspecific lipids from marine, lacustrine, or terrestrial food resources: potential impact on early African Homo sapiens. Comp Biochem Physiol B Biochem Mol Biol 2002;131: 653-673.

Budowski P, Crawford MA: $\alpha$-Linolenic acid as a regulator of the metabolism of arachidonic acid: dietary implications of the ratio, $n-6$ : n-3 fatty acids. Proc Nutr Soc 1985;44:221229.

Budowski P, Leighfield MJ, Crawford MA: Nutritional encephalomalacia in the chick: an exposure of the vulnerable period for cerebellar development and the possible need for both $n-6$ and n-3 fatty acids. Br J Nutr 1987; 58:511-520.

Buydens-Branchey L, Branchey M: n-3 polyunsaturated fatty acids decrease anxiety feelings in a population of substance abusers. J Clin Psychopharmacol 2006;26:661-665.

Calon F, Lim GP, Yang F, et al: Docosahexaenoic acid protects from dendritic pathology in an Alzheimer's disease mouse model. Neuron 2004;43:633-645.
Carlson SE, Werkman SH: A randomized trial of visual attention of preterm infants fed docosahexaenoic acid until two months. Lipids 1996;31:85-90

Catalan J, Moriguchi T, Slotnick B, Murthy M, Greiner RS, Salem N Jr: Cognitive deficits in docosahexaenoic acid-deficient rats. Behavioral neuroscience 2002;116:1022-1031.

-Chalon S, Delion-Vancassel S, Belzung C, Guilloteau D, Leguisquet AM, Besnard JC, Durand G: Dietary fish oil affects monoaminergic neurotransmission and behavior in rats. J Nutr 1998;128:2512-2519.

-Chen B, Dowlatshahi D, MacQueen GM, Wang JF, Young LT: Increased hippocampal BDNF immunoreactivity in subjects treated with antidepressant medication. Biol Psychiatry 2001;50:260-265

Chen S, Gjerde AU, Holmsen H, Nerdal W: Importance of polyunsaturated acyl chains in chlorpromazine interaction with phosphatidylserines: a ${ }^{13} \mathrm{C}$ and ${ }^{31} \mathrm{P}$ solid-state NMR study. Biophys Chem 2005;117:101-109.

-Chisaki K, Okuda Y, Suzuki S, Miyauchi T, Soma M, Ohkoshi N, Sone H, Yamada N, Nakajima $\mathrm{T}$ : Eicosapentaenoic acid suppresses basal and insulin-stimulated endothelin-1 production in human endothelial cells. Hypertens Res 2003:26:655-661.

-Cho E, Hung S, Willett WC, Spiegelman D, Rimm EB, Seddon JM, Colditz GA, Hankinson SE: Prospective study of dietary fat and the risk of age-related macular degeneration. Am J Clin Nutr 2001;73:209-218.

- Chong EW, Kreis AJ, Wong TY, Simpson JA, Guymer RH: Dietary omega-3 fatty acid and fish intake in the primary prevention of agerelated macular degeneration: a systematic review and meta-analysis. Arch Ophthalmol 2008; 126:826-833.

Chua B, Flood V, Rochtchina E, Wang JJ, Smith W, Mitchell P: Dietary fatty acids and the 5year incidence of age-related maculopathy. Arch Ophthalmol 2006;124:981-986.

Clemons TE, Milton RC, Klein R, Seddon JM, Ferris FL 3rd; AgREDS Group: Risk factors for the incidence of Advanced Age-Related Macular Degeneration in the Age-Related Eye Disease Study (AREDS), AREDS report No. 19. Ophthalmology 2005;112:533-539.

Cole GM, Frautschy SA: Docosahexaenoic acid protects from amyloid and dendritic pathology in an Alzheimer's disease mouse model. Nutr Health 2006;18:249-259.

Conquer JA, Tierney MC, Zecevic J, Bettger WJ, Fisher RH: Fatty acid analysis of blood plasma of patients with Alzheimer's disease, other types of dementia, and cognitive impairment. Lipids 2000;35:1305-1312.

-Conway CR, Sheline YI, Chibnall JT, George MS, Fletcher JW, Mintun MA: Cerebral blood flow changes during vagus nerve stimulation for depression. Psychiatry Res 2006; 146: 179-184. 
Crawford M: Placental delivery of arachidonic and docosahexaenoic acids: implications for the lipid nutrition of preterm infants. Am J Clin Nutr 2000;71(1 suppl):275S-284S.

Crawford MA: Lipids and development of the human brain. Biochem Soc trans 1976;4: 231-233.

-Crawford MA, Casperd NM, Sinclair AJ: The long chain metabolites of linoleic and linolenic acids in liver and brain in herbivores and carnivores. Comp Biochem Physiol B 1976a;54:395-401.

Crawford MA, Crawford SM: What We Eat Today. London, Spearman, 1972, p 142.

Crawford MA, Cunnane SC, Harbige LS: A new theory of evolution: quantum theory; in Sinclair AJ, Gibson NA (eds): 3rd International Congress on Essential Fatty Acids and Eicosanoids. American Oil Chemists' Society, Adelaide, 1993, pp 87-95.

-Crawford MA, Golfetto I, Bistanis D, Ghebremeskel K, Min Y, Moodley T, Poston L, Phylactos A, Cunnane S, Schmidt W: Arachidonic and docosahexaenoic acids in protection against central nervous system damage in preterm infants. Lipids 2003;38:303-315.

-Crawford MA, Hassam AG, Williams G: Essential fatty acids and foetal brain growth. Lancet $1976 b ; 1: 452-453$.

Crawford MA, Leigh Broadhurst C, Galli C, Ghebremeskel K, Holmsen H, Saugstad LF, Schmidt F, Sinclair AJ, Cunnane SC: The role of docosahexaenoic and arachidonic acids as determinants of evolution and hominid brain development; in Tsukamoto K, Kawamura T, Takeuchi T, Beard TD Jr, Kaiser MJ (eds): Fisheries for Global Welfare and Environment. 5th World Fisheries Cong 2008, pp $57-76$

Crawford MA, Sinclair AJ: Nutritional influences in the evolution of mammalian brain; in Lipids, Malnutrition and the Developing Brain. Ciba Found Symp, 1972, pp 267-292.

-Cukierman-Yaffee T: The relationship between dysglycemia and cognitive dysfunction. Curr Opin Investig Drugs 2009;10:70-74.

-De Caterina R, Cybulsky MI, Clinton SK, Gimbrone MA Jr, Libby P: The omega-3 fatty acid docosahexaenoate reduces cytokineinduced expression of proatherogenic and proinflammatory proteins in human endothelial cells. Arterioscler Thromb 1994;14: 1829-1836.

-Delcourt C, Carriere I, Cristol JP, Lacroux A, Gerber M: Dietary fat and the risk of age-related maculopathy: the POLANUT study. Eur J Clin Nutr 2007;61:1341-1344.

- Delcourt C, Michel F, Colvez A, Lacroux A, Delage M, Vernet MH: Associations of cardiovascular disease and its risk factors with age-related macular degeneration: the POLA study. Ophthalmic Epidemiol 2001;8:237-249.

- DeMar JC Jr, et al: One generation of $\mathrm{n}-3$ polyunsaturated fatty acid deprivation increases depression and aggression test scores in rats. J Lipid Res 2006;47:172-180. de Sá Roriz-Filho J, De-Sá-Roriz TM, Rosset I, Camozzato AL, Santos AC, Chaves ML Moriguti JC, Roriz-Cruz M: (Pre)diabetes, brain aging, and cognition. Biochim Biophys Acta 2008; 1792:432-443.

Doyle W, Crawford MA, Wynn AHA, Wynn SW: Maternal nutrient intake and birth weight. J Hum Nutr Diet 1989;2:407-414.

Ellis EF, Police RJ, Dodson LY, McKinney JS, Holt SA: Effect of dietary n-3 fatty acids on cerebral microcirculation. Am J Physiol 1992;262:H1379-H1386.

Enard W, Khaitovich P, Klose J, et al: Intra- and interspecific variation in primate gene expression patterns. Science 2002;296:340343.

Engelhart MJ, Geerlings MI, Ruitenberg A, Van Swieten JC, Hofman A, Witteman JC, Breteler MM: Diet and risk of dementia: does fat matter? The Rotterdam Study. Neurology 2002;59:1915-1921.

Espinosa-Heidmann DG, Sall J, Hernandez EP, Cousins SW: Basal laminar deposit formation in APO B100 transgenic mice: complex interactions between dietary fat, blue light, and vitamin E. Invest Ophthalmol Vis Sci 2004;45:260-266.

Fiennes RN, Sinclair AJ, Crawford MA: Essential fatty acid studies in primates linolenic acid requirements of capuchins. J Med Primatol 1973;2:155-169.

Fliesler SJ, Anderson RE: Chemistry and metab olism of lipids in the vertebrate retina. Prog Lipid Res 1983;22:79-131.

Florent S, Malaplate-Armand C, Youssef I, et al: Docosahexaenoic acid prevents neuronal apoptosis induced by soluble amyloid-beta oligomers. J Neurochem 2006;96:385-395.

-Fontani G, Corradeschi F, Felici A, Alfatti F, Bugarini R, Fiaschi AI, Cerretani D, Montorfano G, Rizzo AM, Berra B: Blood profiles, body fat and mood state in healthy subjects on different diets supplemented with omega3 polyunsaturated fatty acids. Eur J Clin Invest 2005;35:499-507.

-Frangou S, Lewis M, McCrone P: Efficacy of ethyleicosapentaenoic acid in bipolar depression: randomised double-blind placebo-controlled study. Br J Psychiatry 2006;188:46-50.

Frangou S, Lewis M, Wollard J, Simmons A: Preliminary in vivo evidence of increased $\mathrm{N}$ acetyl-aspartate following eicosapentanoic acid treatment in patients with bipolar disorder. J Psychopharmacol 2007;21:435-439.

Frasure-Smith N, Lesperance F, Julien P: Major depression is associated with lower omega-3 fatty acid levels in patients with recent acute coronary syndromes. Biol Psychiatry 2004; 55:891-896.

Freeman MP, Hibbeln JR, Wisner KL, Brumbach $\mathrm{BH}$, Watchman M, Gelenberg AJ: Randomized dose-ranging pilot trial of omega- 3 fatty acids for postpartum depression. Acta Psychiatr Scand 2006;113:31-35.
-Freund-Levi Y, Eriksdotter-Jonhagen M, Cederholm T, Basun H, Faxen-Irving G, Garlind A, Vedin I, Vessby B, Wahlund LO, Palmblad $\mathrm{J}$ : Omega-3 fatty acid treatment in 174 patients with mild to moderate Alzheimer disease: OmegAD study: a randomized doubleblind trial. Archives of Neurology 2006;63: 1402-1408.

Friedman DA, Lukiw WJ, Hill JM: Apolipoprotein $\mathrm{E}$ epsilon 4 offers protection against agerelated macular degeneration. Med Hypotheses 2007;68:1047-1055

Galli C, Socini A: Dietary lipids in pre- and postnatal development; in Perkins EG, Visek WJ (eds): Dietary Fats and Health; American Oil Chemists' Society, Chicago, 1983, pp 278301.

- Gardier A: Mechanism of action of antidepressant drugs: importance of genetically modified mice in the pharmacological in vivo approach (article in French). Therapie 2005;60: 469-476.

- Gesch CB, Hammond SM, Hampson SE, Eves A, Crowder MJ: Influence of supplementary vitamins, minerals and essential fatty acids on the antisocial behaviour of young adult prisoners: randomised, placebo-controlled trial. Br J Psychiatry 2002;181:22-28.

Gomez-Pinilla F: Brain foods: the effects of nutrients on brain function. Nat Rev 2008;9: 568-578.

Green KN, Martinez-Coria H, Khashwji H, Hall EB, Yurko-Mauro KA, Ellis L, LaFerla FM: Dietary docosahexaenoic acid and docosapentaenoic acid ameliorate amyloid-beta and tau pathology via a mechanism involving presenilin 1 levels. J Neurosci 2007;27:4385-4395.

- Greiner RS, Moriquchi T, Slotnick BM, Hutton A, Salem N: Olfactory discrimination deficits in n-3 fatty acid-deficient rats. Physiol Behav 2001;72:379-385.

-Grenyer BF, Crowe T, Meyer B, Owen AJ, Grigonis-Deane EM, Caputi P, Howe PR: Fish oil supplementation in the treatment of major depression: A randomised double-blind placebo-controlled trial. Prog Neuropsychopharmacol Biol Psychiatry 2007;31:1393-1396.

-Hakkarainen R, Partonen T, Haukka J, Virtamo J, Albanes D, Lonnqvist J: Is low dietary intake of omega-3 fatty acids associated with depression? Am J Psychiatry 2004;161:567-569.

-Hamazaki T, Sawazaki S, Itomura M, Asaoka E, Nagao Y, Nishimura N, Yazawa K, Kuwamori T, Kobayashi M: The effect of docosahexaenoic acid on aggression in young adults: a placebo-controlled double-blind study. J Clin Invest 1996;97:1129-1133.

- Hamazaki T, Thienprasert A, Kheovichai K, Samuhaseneetoo S, Nagasawa T, Watanabe $S$ : The effect of docosahexaenoic acid on aggression in elderly Thai subjects: a placebocontrolled double-blind study. Nutr Neurosci 2002;5:37-41.

-Haubner LY, Stockard JE, Saste MD, et al: Maternal dietary docosahexanoic acid content affects the rat pup auditory system. Brain Res Bull 2002;58:1-5. 
-Heuberger RA, Mares Perlman JA, Klein R, Klein BE, Millen AE, Palta M: Relationship of dietary fat to age-related maculopathy in the Third National Health and Nutrition Examination Survey. Arch Ophthalmol 2001; 119:1833-1838.

Hibbeln JR: Fish consumption and major depression. Lancet 1998;351:1213.

-Hibbeln JR: Seafood consumption, the DHA content of mothers' milk and prevalence rates of postpartum depression: a cross-national, ecological analysis. J Affect Disord 2002;69:15-29.

-Hibbeln JR, Ferguson TA, Blasbalg TL: Omega-3 fatty acid deficiencies in neurodevelopment, aggression and autonomic dysregulation: opportunities for intervention. Int Rev Psychiatry 2006a;18:107-118.

Hibbeln JR, Nieminen LR, Blasbalg TL, Riggs JA, Lands WE: Healthy intakes of $n-3$ and n-6 fatty acids: estimations considering worldwide diversity. Am J Clin Nutr 2006b; 83(suppl):1483S-1493S.

-Hibbeln JR, Nieminen LR, Lands WE: Increasing homicide rates and linoleic acid consumption among five Western countries, 1961-2000. Lipids 2004;39:1207-1213.

-Hindenes JO, Nerdal W, Guo W, Di L, Small DM, Holmsen H: Physical properties of the transmembrane signal molecule, sn-1-stearoyl 2arachidonoylglycerol. Acyl chain segregation and its biochemical implications. J Biol Chem 2000;275:6857-6867.

Horrocks LA, Yeo YK: Health benefits of docosahexaenoic acid (DHA). Pharmacol Res 1999;40:211-225.

-Huang TL, Zandi PP, Tucker KL, Fitzpatrick AL, Kuller LH, Fried LP, Burke GL, Carlson MC: Benefits of fatty fish on dementia risk are stronger for those without APOE epsilon4. Neurology 2005;65:1409-1414.

-Iribarren C, Markovitz JH, Jacobs DR Jr, Schreiner PJ, Daviglus M, Hibbeln JR: Dietary intake of $n-3, n-6$ fatty acids and fish: relationship with hostility in young adults: the CARDIA study. Eur J Clin Nutr 2004;58:24-31.

-Itomura M, Hamazaki K, Sawazaki S, Kobayashi M, Terasawa K, Watanabe S, Hamazaki T: The effect of fish oil on physical aggression in schoolchildren: a randomized, doubleblind, placebo-controlled trial. J Nutr Biochem 2005;16:163-171.

-Jacka FN, Pasco JA, Henry MJ, Kotowicz MA, Nicholson GC, Berk M: Dietary omega-3 fatty acids and depression in a community sample. Nutr Neurosci 2004; 7:101-106.

- Jager RD, Mieler WF, Miller JW: Age-related macular degeneration. N Engl J Med 2008; 358:2606-2617.

James MJ, Cleland LG: Applying a research ethics committee approach to a medical practice controversy: the case of the selective COX-2 inhibitor rofecoxib. J Med Ethics 2004;30: 182-184.

Jump DB: The biochemistry of $\mathrm{n}-3$ polyunsaturated fatty acids. J Biol Chem 2002;277:87558758 .
Kalmijn S, Feskens EJ, Launer LJ, Kromhout D: Polyunsaturated fatty acids, antioxidants, and cognitive function in very old men. Am J Epidemiol 1997;145:33-41.

Katsumata T, Katayama Y, Obo R, Muramatsu H, Ohtori T, Terashi A: Delayed administration of ethyl eicosapentate improves local cerebral blood flow and metabolism without affecting infarct volumes in the rat focal ischemic model. Eur J Pharmacol 1999;372: 167-174.

Keck PE Jr, Mintz J, McElroy SL, Freeman MP, Suppes T, Frye MA, Altshuler LL, Kupka R, Nolen WA, Leverich GS, et al: Double-blind, randomized, placebo-controlled trials of ethyl-eicosapentanoate in the treatment of bipolar depression and rapid cycling bipolar disorder. Biol Psychiatry 2006;60:1020-1022.

Kelley DS, Taylor PC, Nelson GJ, Schmidt PC, Ferretti A, Erickson KL, Yu R, Chandra RK, Mackey BE: Docosahexaenoic acid ingestion inhibits natural killer cell activity and production of inflammatory mediators in young healthy men. Lipids 1999;34:317-324.

Kitajka K, et al: Effects of dietary omega-3 polyunsaturated fatty acids on brain gene expression. Proc Natl Acad Sci USA 2004; 101: 10931-10936.

-Kodas E, Galineau L, Bodard S, Vancassel S, Guilloteau D, Besnard JC, Chalon S: Serotoninergic neurotransmission is affected by $\mathrm{n}-3$ polyunsaturated fatty acids in the rat. $\mathrm{J}$ Neurochem 2004;89:695-702.

Kotani S, Sakaguchi E, Warashina S, Matsukawa N, Ishikura Y, Kiso Y, Sakakibara M, Yoshimoto T, Guo J, Yamashima T: Dietary supplementation of arachidonic and docosahexaenoic acids improves cognitive dysfunction. Neurosci Res 2006;56:159-164.

Lagarde M, Bernoud N, Brossard N, LemaitreDelaunay D, Thiès F, Croset M, Lecerf J: Lysophosphatidylcholine as a preferred carrier form of docosahexaenoic acid to the brain. J Mol Neurosci 2001;16:201-204; discussion 215-221.

Lands WEM: A critique of paradoxes in current advice on dietary lipids. Prog Lipid Res 2008; 77-106.

-Lauritzen L, Hansen HS, Jùrgensen MH, Michaelsen KF: The essentiality of long chain $\mathrm{n}-3$ fatty acids in relation to development and function of the brain and retina. Prog Lipid Res 2001;40:1-94.

Leaf AA, Leighfield MJ, Costeloe KL, Crawford MA: Factors affecting long-chain polyunsaturated fatty acid composition of plasma choline phosphoglycerides in preterm infants. J Pediatr Gastroenterol Nutr 1992;14:300308.

Leone S, Ottani A, Bertolini A: Dual acting antiinflammatory drugs. Curr Top Med Chem 2007;7:265-275.

Leyton J, Drury PJ, Crawford MA: Differential oxidation of saturated and unsaturated fatty acids in vivo in the rat. Br J Nutr 1987;57: 383-393.
Lim GP, Calon F, Morihara T, Yang F, Teter B, Ubeda O, Salem N Jr, Frautschy SA, Cole GM: A diet enriched with the omega-3 fatty acid docosahexaenoic acid reduces amyloid burden in an aged Alzheimer mouse model. J Neurosci 2005;25:3032-3040.

Liotti M, Mayberg HS, McGinnis S, Brannan SL, Jerabek P: Unmasking disease-specific cerebral blood flow abnormalities: mood challenge in patients with remitted unipolar depression. Am J Psychiatry 2002;159:18301840.

Lukiw WJ, Bazan NG: Docosahexaenoic acid and the aging brain. J Nutr 2008;138:25102514.

Lukiw WJ, Cui JG, Marcheselli VL, Bodker M, Botkjaer A, Gotlinger K, Serhan CN, Bazan NG: A role for docosahexaenoic acid-derived neuroprotectin D1 in neural cell survival and Alzheimer disease. J Clin Invest 2005; 115:2774-2783.

-Maes M, Meltzer HY, Bosmans E, Bergmans R, Vandoolaeghe E, Ranjan R, Desnyder R: Increased plasma concentrations of interleukin-6, soluble interleukin-6, soluble interleukin-2 and transferrin receptor in major depression. J Affect Disord 1995;34:301309.

-Malek G, Johnson LV, Mace BE, Saloupis P, Schmechel DE, Rickman DW, Toth CA, Sullivan PM, Rickman CB: Apolipoprotein E allele-dependent pathogenesis: a model for age-related retinal degeneration. Proc Natl Acad Sci USA 2005;102:11900-11905.

Mamounas LA, Altar CA, Blue ME, Kaplan DR, Tessarollo L, Lyons WE: DNF promotes the regenerative sprouting, but not survival, of injured serotonergic axons in the adult rat brain. J Neurosci 2000;20:771-782.

Marangell LB, Martinez JM, Zboyan HA, Kertz B, Kim HF, Puryear LJ: A double-blind, placebo-controlled study of the omega-3 fatty acid docosahexaenoic acid in the treatment of major depression. Am J Psychiatry 2003; 160:996-998.

Marcheselli VL, Hong S, Lukiw WJ, et al: Novel docosanoids inhibit brain ischemia-reperfusion-mediated leukocyte infiltration and pro-inflammatory gene expression. J Biol Chem 2003;278:43807-43817.

-Mares-Perlman JA, Brady WE, Klein R, VandenLangenberg GM, Klein BE, Palta M: Dietary fat and age-related maculopathy. Arch Ophthalmol 1995;113:743-748.

Martinez M, Vazquez E: MRI evidence that docosahexaenoic acid ethyl ester improves myelination in generalized peroxisomal disorders. Neurology 1998;51:26-32.

-McNamara RK, Hahn CG, Jandacek R, Rider T, Tso P, Stanford KE, Richtand NM: Selective deficits in the omega-3 fatty acid docosahexaenoic acid in the postmortem orbitofrontal cortex of patients with major depressive disorder. Biol Psychiatry 2007;62:17-24.

Mohrhauer H, Holman RT: Effect of linolenic acid upon the metabolism of linoleic acid. J Nutr 1963;81:67-74. 
Morris MC, Evans DA, Bienias JL, Tangney CC, Bennett DA, Wilson RS, Aggarwal N, Schneider J: Consumption of fish and n-3 fatty acids and risk of incident Alzheimer disease. Arch Neurol 2003;60:940-946.

-Murck H, Manku M: Ethyl-EPA in Huntington disease: potentially relevant mechanism of action. Brain Res Bull 2007;72:159-164.

-Nemets B, Stahl Z, Belmaker RH: Addition of omega-3 fatty acid to maintenance medication treatment for recurrent unipolar depressive disorder. Am J Psychiatry 2002;159: 477-479.

-Nemets H, Nemets B, Apter A, Bracha Z, Belmaker RH: Omega-3 treatment of childhood depression: a controlled, double-blind pilot study. Am J Psychiatry 2006;163:1098-1100.

Neu P, Schlattmann P, Schilling A, Hartmann A: Cerebrovascular reactivity in major depression: a pilot study. Psychosom Med 2004;66: $6-8$.

Neuringer M, Connor WE, Lin DS, Barstad L, Luck S: Biochemical and functional effects of prenatal and postnatal n-3 fatty acid deficiency on retina and brain in rhesus monkeys. Proc Natl Acad Sci USA 1986;83:40214025.

Nibuya M, Morinobu S, Duman RS: Regulation of BDNF and trkB mRNA in rat brain by chronic electroconvulsive seizure and antidepressant drug treatments. J Neurosci 1995; 15:7539-7547.

Noaghiul S, Hibbeln JR: Cross-national comparisons of seafood consumption and rates of bipolar disorders. Am J Psychiatry 2003;160: 2222-2227.

-Oksman M, Iivonen H, Hogyes E, Amtul Z, Penke B, Leenders I, Broersen L, Lutjohann D, Hartmann T, Tanila H: Impact of different saturated fatty acid, polyunsaturated fatty acid and cholesterol containing diets on beta-amyloid accumulation in APP/PS1 transgenic mice. Neurobiol Dis 2006;23: 563-572.

Orr SK, Bazinet RP: The emerging role of docosahexaenoic acid in neuroinflammation. Curr Opin Investig Drugs 2008;9:735-743.

-Oruch R, Hodneland E, Pryme I, Holmsen H: Effects of psychotropic drugs on polyphosphoinositide metabolism in human platelets: a result of receptor-independent drug intercalation in the plasma membrane? Biochim Biophys Acta, 2008;1778:2165-2176.

-Osher Y, Bersudsky Y, Belmaker RH: Omega-3 eicosapentaenoic acid in bipolar depression: report of a small open-label study. J Clin Psychiatry 2005;66:726-729.

-Otsuka M, Yamaguchi K, Ueki A: Similarities and differences between Alzheimer's disease and vascular dementia from the viewpoint of nutrition. Ann NY Acad Sci 2002;977:155161.

-Parker G, Gibson NA, Brotchie H, Heruc G, Rees AM, Hadzi-Pavlovic D: Omega-3 fatty acids and mood disorders. Am J Psychiatry 2006; 163:969-978.
Peet M: Omega-3 polyunsaturated fatty acids in the treatment of schizophrenia. Israel J Psychiatry Relat Sci 2008;45:19-25.

Peet M, Horrobin DF: A dose-ranging study of the effects of ethyl-eicosapentaenoate in patients with ongoing depression despite apparently adequate treatment with standard drugs. Arch Gen Psychiatry 2002;59:913-919.

Pennisi E: Primate evolution: gene activity clocks brain's fast evolution. Science 2002;296:233235.

Prasad MR, Lovell MA, Yatin M, Dhillon H, Markesbery WR: Regional membrane phospholipid alterations in Alzheimer's disease. Neurochem Res 1998;23:81-88.

Puri BK, Counsell SJ, Richardson AJ, Horrobin DF: Eicosapentaenoic acid in treatment-resistant depression. Arch Gen Psychiatry 2002;59:91-92.

Puri BK, Leavitt BR, Hayden MR, et al: EthylEPA in Huntington disease: a double-blind, randomized, placebo-controlled trial. Neurology 2005;65:286-292.

Raeder MB, Steen VM, Vollset SE, Bjelland I: Associations between cod liver oil use and symptoms of depression: the Hordaland Health Study. J Affect Disord 2007;101:245-249.

Raison CL, Capuron L, Miller AH: Cytokines sing the blues: inflammation and the pathogenesis of depression. Trends Immunol 2006; 27:24-31.

-Rao JS, Ertley RN, Demar JC Jr, Rapoport SI, Bazinet RP, Lee HJ: Dietary n-3 PUFA deprivation alters expression of enzymes of the arachidonic and docosahexaenoic acid cascades in rat frontal cortex. Mol Psychiatry 2007a; 12:151-157.

-Rao JS, Ertley RN, Lee HJ, DeMar JC Jr, Arnold JT, Rapoport SI, Bazinet RP: $\mathrm{n}-3$ polyunsaturated fatty acid deprivation in rats decreases frontal cortex BDNF via a p38 MAPKdependent mechanism. Mol Psychiatry 2007b;12:36-46.

-Rapoport SI, Rao JS, Igarashi M: Brain metabolism of nutritionally essential polyunsaturated fatty acids depends on both the diet and the liver. Prostaglandins Leukot Essent Fatty Acids 2007;77:251-261.

Ray WA, Stein CM, Daugherty JR, et al: COX-2 selective non-steroidal antiinflammatory drugs and risk of serious coronary heart disease. Lancet 2002;360:1071-1073.

-Rees G, Doyle W, Srivastava A, Brooke ZM, Crawford MA, Costeloe KL: The nutrient intakes of mothers of low birth weight babies: a comparison of ethnic groups in East London, UK. Matern Child Nutr 2005;1:91-99.

Resnikoff S, Pascolini D, Etya'ale D, Kocur I, Pararajasegaram R, Pokharel GP, Mariotti SP: Global data on visual impairment in the year 2002. Bull World Health Organ 2004; 82:844-851.

Robman L, Vu H, Hodge A, Tikellis G, Dimitrov P, McCarty C, Guymer R: Dietary lutein, zeaxanthin, and fats and the progression of age-related macular degeneration. Can J Ophthalmol 2007;42:720-726.
Ross BM, Seguin J, Sieswerda LE: Omega-3 fatty acids as treatments for mental illness: which disorder and which fatty acid? Lipids Health Dis 2007;6:21.

Samieri C, Féart C, Letenneur L, Dartigues JF, Pérès K, Auriacombe S, Peuchant E, Delcourt C, Barberger-Gateau P: Low plasma eicosapentaenoic acid and depressive symptomatology are independent predictors of dementia risk. Am J Clin Nutr 2008;88:714721.

-Sanchez-Villegas A, Henríquez P, Figueiras A, Ortuño F, Lahortiga F, Martínez-González MA: Long chain omega-3 fatty acids intake, fish consumption and mental disorders in the SUN cohort study. Eur J Nutr 2007;46: 337-346.

SanGiovanni JP, Chew EY: The role of omega-3 long-chain polyunsaturated fatty acids in health and disease of the retina. Prog Retin Eye Res 2005;24:87-138.

SanGiovanni JP, Chew EY, Agron E, Clemons TE, Ferris FL 3rd, Gensler G, Lindblad AS, Milton RC, Seddon JM, Klein R, et al: The relationship of dietary omega-3 long-chain polyunsaturated fatty acid intake with incident age-related macular degeneration: AREDS report no. 23. Arch Ophthalmol 2008;126:1274-1279.

SanGiovanni JP, Chew EY, Clemons TE, et al: The relationship of dietary lipid intake and age-related macular degeneration in a casecontrol study: AREDS Report No. 20. Arch Ophthalmol 2007;125:671-679.

Schaefer EJ, Bongard V, Beiser AS, Lamon-Fava S, Robins SJ, Au R, Tucker KL, Kyle DJ, Wilson PW, Wolf PA: Plasma phosphatidylcholine docosahexaenoic acid content and risk of dementia and Alzheimer disease: the Framingham Heart Study. Arch Neurol 2006;63:1545-1550.

Schaumberg DA, Christen WG, Hankinson SE, Glynn RJ: Body mass index and the incidence of visually significant age-related maculopathy in men. Arch Ophthalmol 2001;119:1259-1265.

-Schins A, Crijns HJ, Brummer RJ, Wichers M, Lousberg R, Celis S, Honig A: Altered omega-3 polyunsaturated fatty acid status in depressed post-myocardial infarction patients. Acta Psychiatr Scand 2007;115:35-40.

$\checkmark$ Scholl HP, Fleckenstein M, Charbel Issa P, Keilhauer C, Holz FG, Weber BH: An update on the genetics of age-related macular degeneration. Mol Vis 2007;13:196-205.

-Seddon JM, Cote J, Davis N, Rosner B: Progression of age-related macular degeneration: association with body mass index, waist circumference, and waist-hip ratio. Arch Ophthalmol 2003a;121:785-792.

$\checkmark$ Seddon JM, Cote J, Rosner B: Progression of agerelated macular degeneration: association with dietary fat, transunsaturated fat, nuts, and fish intake. Arch Ophthalmol 2003b;121: 1728-1737. 
-Seddon JM, George S, Rosner B: Cigarette smoking, fish consumption, omega-3 fatty acid intake, and associations with age-related macular degeneration: the US Twin Study of Age-Related Macular Degeneration. Arch Ophthalmol 2006;124:995-1001.

-Seddon JM, Rosner B, Sperduto RD, Yannuzzi L, Haller JA, Blair NP, Willett W: Dietary fat and risk for advanced age-related macular degeneration. Arch Ophthalmol 2001;119: 1191-1199.

-Serhan CN, Yacoubian S, Yang R: Anti-inflammatory and proresolving lipid mediators. Annu Rev Pathol 2008;3:279-312.

Shimizu E, Hashimoto K, Okamura N, Koike K, Komatsu N, Kumakiri C, Nakazato M, Watanabe $\mathrm{H}$, Shinoda N, Okada S, et al: Alterations of serum levels of brain-derived neurotrophic factor (BDNF) in depressed patients with or without antidepressants. Biol Psychiatry 2003;54:70-75.

-Silvers KM, Scott KM: Fish consumption and self-reported physical and mental health status. Public Health Nutr 2002;5:427-431.

-Silvers KM, Woolley CC, Hamilton FC, Watts PM, Watson RA: Randomised double-blind placebo-controlled trial of fish oil in the treatment of depression. Prostaglandins Leukot Essent Fatty Acids 2005;72:211-218.

- Sinclair AJ: Incorporation of radioactive polyunsaturated fatty acids into liver and brain of developing rat. Lipids 1975;10:175-184.

- Sinclair AJ, Begg D, Mathai M, Weisinger RS: $\mathrm{n}-3$ fatty acids and the brain: review of studies in depression. Asia Pac J Clin Nutr 2007; 16(suppl 1):391-397.

- Sinclair AJ, Crawford MA: The incorporation of linolenic aid and docosahexaenoic acid into liver and brain lipids of developing rats. FEBS Lett 1972;26:127-129.

- Soderberg M, Edlund C, Kristensson K, Dallner G: Fatty acid composition of brain phospholipids in aging and in Alzheimer's disease. Lipids 1991;26:421-425.

Song C, Horrobin D: Omega-3 fatty acid ethyleicosapentaenoate, but not soybean oil, attenuates memory impairment induced by central IL-1beta administration. J Lipid Res 2004;45:1112-1121.

Sprecher H: Interconversions between 20 - and 22 - carbon n-3 and n-6 fatty acids via 4 -desaturase independent pathways; in Sinclair AJ, Gibson NA (eds): 3rd International Congress on Essential Fatty Acids and Eicosanoids. American Oil Chemists Society, Adelaide, 1993, pp 18-22.

Sprecher H, Chen Q, Yin FQ: Regulation of the biosynthesis of 22:5n-6 and 22:6n-3:a complex intracellular process. Lipids 1999; 34(suppl):S153-S156.

- Stahl LA, Begg DP, Weisinger RS, Sinclair AJ: The role of omega- 3 fatty acids in mood disorders. Curr Opin Investig Drugs 2008;9: 57-64.
Stice E, Spoor S, Bohon C, Small DM, Stice E, Spoor S, Bohon C, Small DM: Relation between obesity and blunted striatal response to food is moderated by TaqIA A1 allele. Science 2008;322:449-452.

-Stoll AL, Locke CA, Marangell LB, Severus WE: Omega-3 fatty acids and bipolar disorder: a review. Prostaglandins Leukot Essent Fatty Acids 1999a;60:329-337.

$\checkmark$ Stoll AL, Severus WE, Freeman MP, Rueter S, Zboyan HA, Diamond E, Cress KK, Marangell LB: $n-3$ fatty acids in bipolar disorder: a preliminary double-blind, placebocontrolled trial. Arch Gen Psychiatry 1999b;56:407-412.

$>$ Su KP, Huang SY, Chiu CC, Shen WW: Omega-3 fatty acids in major depressive disorder. A preliminary double-blind, placebo-controlled trial. Eur Neuropsychopharmacol 2003;13:267-271.

-Suzuki H, Manabe S, Wada O, Crawford MA: Rapid incorporation of docosahexaenoic acid from dietary sources into brain microsomal, synaptosomal and mitochondrial membranes in adult mice. Int J Vit Nutr Res 1997;67:272-278.

-Suzuki H, Morikawa Y, Takahashi H: Effect of DHA oil supplementation on intelligence and visual acuity in the elderly. World Rev Nutr Diet 2001;88:68-71.

-Suzuki S, Akechi T, Kobayashi M, Taniguchi K, Goto K, Sasaki S, Tsugane S, Nishiwaki Y, Miyaoka H, Uchitomi Y: Daily omega-3 fatty acid intake and depression in Japanese patients with newly diagnosed lung cancer. Br J Cancer 2004;90:787-793.

Tanskanen A, Hibbeln JR, Hintikka J, Haatainen K, Honkalampi K, Viinamaki H: Fish consumption, depression, and suicidality in a general population. Arch Gen Psychiatry 2001;58:512-513.

-Tassoni DE, Kaur G, Weisinger RS, Sinclair AJ: The role of eicosanoids in the brain. Asia Pac J Clin Nutr 2008;17(suppl 1):220-228.

-Timonen M, Horrobin D, Jokelainen J, Laitinen J, Herva A, Rasanen P: Fish consumption and depression: the Northern Finland 1966 birth cohort study. J Affect Disord 2004;82: 447-452.

Tully AM, Roche HM, Doyle R, Fallon C, Bruce I, Lawlor B, Coakley D, Gibney MJ: Low serum cholesteryl ester-docosahexaenoic acid levels in Alzheimer's disease: a case-control study. Br J Nutr 2003;89:483-489.

Umhau JC, Dauphinais KM, Patel SH, Nahrwold DA, Hibbeln JR, Rawlings RR, George DT: The relationship between folate and docosahexaenoic acid in men. Eur J Clin Nutr 2006; 60:352-357.

-Underhaug Gjerde A, Holmsen H, Nerdal W: Chlorpromazine interaction with phosphatidylserines: a ${ }^{13} \mathrm{C}$ and ${ }^{31} \mathrm{P}$ solid state NMR study. Biochim Biophys Acta 2004;1682:2837.

Vaddadi KS, Gilleard C, Fryer H: Abuse of carers by relatives with severe mental illness. Int J Soc Psychiatry 2002;48:149-155. van Gelder BM, Tijhuis M, Kalmijn S, Kromhout D: Fish consumption, n-3 fatty acids, and subsequent 5-y cognitive decline in elderly men: the Zutphen Elderly Study. Am J Clin Nutr 2007;85:1142-1147.

Virkkunen ME, Horrobin DF, Jenkins DK, Manku MS: Plasma phospholipid essential fatty acids and prostaglandins in alcoholic, habitually violent, and impulsive offenders. Biol Psychiatry 1987;22:1087-1096.

Vreugdenhil M, Bruehl C, Voskuyl RA, Kang JX, Leaf A, Wadman WJ: Polyunsaturated fatty acids modulate sodium and calcium currents in CA1 neurons. Proc Natl Acad Sci USA 1996;93:12559-12563.

-Walser B, Giordano RM, Stebbins CL: Supplementation with omega-3 polyunsaturated fatty acids augments brachial artery dilation and blood flow during forearm contraction. Eur J Appl Physiol 2006;97:347-354.

Wan M, Li Y, Xue H, Li Q, Li J: Eicosapentaenoic acid inhibits TNF-alpha-induced Lnk expression in human umbilical vein endothelial cells: involvement of the PI3K/Akt pathway. J Nutr Biochem 2007;18:17-22.

Weisinger HS, Vingrys AJ, Bui BV, Sinclair AJ: Effects of dietary n-3 fatty acid deficiency and repletion in the guinea pig retina. Invest Ophthalmol Vis Sci 1999;40:327-338.

Whalley LJ, Deary IJ, Starr JM, Wahle KW, Rance KA, Bourne VJ, Fox HC: n-3 fatty acid erythrocyte membrane content, APOE varepsilon4, and cognitive variation: an observational follow-up study in late adulthood. Am J Clin Nutr 2008;87:449-454.

-Wynn SW, Wynn AHA, Doyle W, Crawford MA: The association of maternal social class with maternal diet and the dimensions of babies in a population of London Women. Nutr Health 1994;9:303-315.

Xiao YF, Sigg DC, Leaf A: The antiarrhythmic effect of $n-3$ polyunsaturated fatty acids: modulation of cardiac ion channels as a potential mechanism. Membr Biol: 2005;206: 141-154.

Yates JR, Sepp T, Matharu BK, et al: Complement $\mathrm{C} 3$ variant and the risk of age-related macular degeneration. N Engl J Med 2007;357: 553-561.

Yavin E, Himovichi E, Eilam R: Delayed cell migration in the developing rat brain following maternal Omega 3 alpha linolenic acid dietary deficiency. Neuroscience 2009; May 14, E-pub ahead of print.

Zanarini MC, Frankenburg FR: omega-3 Fatty acid treatment of women with borderline personality disorder: a double-blind, placebo-controlled pilot study. Am J Psychiatry 2003;160:167-169.

-Zimmer L, Vancassel S, Cantagrel S, Breton P, Delamanche S, Guilloteau D, Durand G, Chalon S: The dopamine mesocorticolimbic pathway is affected by deficiency in $n-3$ polyunsaturated fatty acids. Am J Clin Nutr 2002;75:662-667. 